Estuaries And Coasts

September 2015, Volume 38 Issue 5 Pages 1593-1618

http://dx.doi.org/10.1007/s12237-014-9899-x

http://archimer.ifremer.fr/doc/00275/38624/

(c) Her Majesty the Queen in Right of Canada as represented by the

Department of Fisheries and Oceans 2014

\title{
Climate Change Influences Carrying Capacity in a Coastal Embayment Dedicated to Shellfish Aquaculture
}

\author{
Guyondet T. ${ }^{1,{ }^{*}}$, Comeau L. A. ${ }^{1}$, Bacher Cedric ${ }^{2}$, Grant J. ${ }^{3}$, Rosland R. ${ }^{4}$, Sonier R. ${ }^{1}$, Filgueira R. ${ }^{1}$ \\ ${ }^{1}$ Gulf Fisheries Ctr, Sci Branch, Dept Fisheries \& Oceans, Moncton, NB E1C 9B6, Canada. \\ 2 IFREMER, Ctr Brest, F-29280 Plouzane, France. \\ ${ }^{3}$ Dalhousie Univ, Dept Oceanog, Halifax, NS B3H 4J1, Canada. \\ ${ }^{4}$ Univ Bergen, Dept Biol, N-5020 Bergen, Norway. \\ *Corresponding author : Thomas Guyondet, email address : thomas.guyondet@dfo-mpo.gc.ca
}

\begin{abstract}
:
A spatially explicit coupled hydrodynamic-biogeochemical model was developed to study a coastal ecosystem under the combined effects of mussel aquaculture, nutrient loading and climate change. The model was applied to St Peter's Bay (SPB), Prince Edward Island, Eastern Canada. Approximately $40 \%$ of the SPB area is dedicated to mussel (Mytilus edulis) longline culture. Results indicate that the two main food sources for mussels, phytoplankton and organic detritus, are most depleted in the central part of the embayment. Results also suggest that the system is near its ultimate capacity, a state where the energy cycle is restricted to nitrogen-phytoplankton-detritus-mussels with few resources left to be transferred to higher trophic levels. Annually, mussel meat harvesting extracts nitrogen $(\mathrm{N})$ resources equivalent to $42 \%$ of river inputs or $46.5 \%$ of the net phytoplankton primary production. Under such extractive pressure, the phytoplankton biomass is being curtailed to 1980's levels when aquaculture was not yet developed and $\mathrm{N}$ loading was half the present level. Current mussel stocks also decrease bayscale sedimentation rates by $14 \%$. Finally, a climate change scenario (year 2050) predicted a $30 \%$ increase in mussel production, largely driven by more efficient utilization of the phytoplankton spring bloom. However, the predicted elevated summer temperatures (> $25 \mathrm{~A}$ degrees $\mathrm{C}$ ) may also have deleterious physiological effects on mussels and possibly increase summer mortality levels. In conclusion, cultivated bivalves may play an important role in remediating the negative impacts of landderived nutrient loading. Climate change may lead to increases in production and ecological carrying capacity as long as the cultivated species can tolerate warmer summer conditions.
\end{abstract}

Keywords : Climate change, Nutrient loading, Mussel culture, Carrying capacity, Coastal ecosystem, Numerical modelling 


\section{INTRODUCTION}

The rapid development of bivalve aquaculture over the last few decades (FAO 2012) has highlighted its role in promoting economic development in coastal communities while potentially risking depletion of local nutrient resources, via grazing. Given the critical food production service provided by this activity, it is recognized that modern aquaculture governance must be primarily targeted towards the sustainable development and management of this industry (Hishamunda et al. 2014).

In this context, carrying capacity is a widely used concept that encompasses four aspects namely physical, production, ecological and social carrying capacity (Inglis et al. 2000, McKindsey et al. 2006). Most of the recent literature on the carrying capacity of coastal ecosystems for bivalve culture has been directed at the production and ecological components and at providing knowledge and developing tools to inform the decision-making process of coastal management in building a sustainable shellfish aquaculture sector (Brigolin et al. 2009, Byron et al. 2011b, Dabrowski et al. 2013, Ferreira et al. 2008, Filgueira et al. 2013). While production carrying capacity represents the stock that maximizes harvest, the ecological component is defined as the stock causing ecological impacts, such as decreased phytoplankton abundance, organic enrichment of the sediment or changes in nutrient cycling, of an unacceptable intensity (Inglis et al. 2000, McKindsey et al. 2006).

It should be noted that coastal regions are subject to multiple pressures (fishing, waste water discharge, agricultural run-off) and are a major provider of goods and services besides aquaculture yield (Costanza et al. 1997). Bivalve aquaculture itself may provide such services as the bioremediation of eutrophication symptoms due to excessive nutrient run-off (Carmichael et al. 2012, Gifford et al. 2005, Gren et al. 2009, Lindahl et al. 2005). There are multiple research programs worldwide directed toward this mitigation goal via bivalve aquaculture (EPA Regional Ecosystem Services Program in Long Island Sound, USA; MuMiHus project in Denmark with collaborations in Canada and New Zealand; Aquabest and Submariner projects in the Baltic Sea). Ecosystem-based management is the approach recommended to account for the interaction of natural processes and human activities in realizing the sustainable development of these areas, in particular for bivalve aquaculture (Byron et al. 2011a, Cranford et al. 2012, Soto et al. 2008). Sound scientific knowledge is needed to support an ecosystem-based approach to aquaculture management (Rice et al. 2005). Investigations should not be limited to a single aspect or single activity but designed to further our understanding of coastal system dynamics under a combination of different pressures (McLeod and Leslie 2009).

In Prince Edward Island (PEI), on the Atlantic coast of Canada, commercial mussel (Mytilus edulis) aquaculture started in the 1980's and expanded rapidly in the 1990's to reach a 20,900 metric ton production in 2011, representing over $70 \%$ of total Canadian mussel landings (DFO 2006, Smith and Ramsay 2012, Statistics Canada 2011). The coastal embayments that supported this developing industry also experienced increasing nutrient run-off due to changes in land-use 
during the 1980's and 1990's (Cairns 2002, Raymond et al. 2002). In 2011agricultural land was covering $42.5 \%$ of PEI, most of which (69\%) was used to grow various types of crops (Statistics Canada Census of Agriculture, http://www.statcan.gc.ca/pub/95-640-x/2012002eng.htm). The land-water connection is so strong that relationships were established between phytoplankton biomass in the coastal systems and the area of agricultural land in their drainage basin (Meeuwig 1999).

The objective of the present study is to take advantage of this tight land-sea coupling characteristic of PEI coastal embayments to investigate the combined effects of mussel aquaculture and land-derived nutrient loading on the aquatic ecosystem. More specifically, this case study employs a spatially-explicit coupled hydrodynamic-biogeochemical model to address the issues of production and ecological carrying capacity and the potential for mussel culture to mitigate the effects of nutrient inputs. Moreover, since climate change has the potential to interact with several coastal ecosystem processes (Scavia et al. 2002), it is considered here as a forcing variable in combination with the above mentioned pressures. In addition to the baseline (2011), two temperature climatology scenarios were tested in order to address the evolution of this forcing from the onset of commercial mussel culture in the 1980's up to the predicted conditions of year 2050 .

\section{MATERIALS AND METHODS}

\subsection{Study area}

St Peter's Bay $(\mathrm{SPB})$ is an elongated $(13 \times 2 \mathrm{~km})$ coastal inlet located on the north shore of PEI, Canada (Fig. 1). It opens onto the Gulf of Saint-Lawrence through a 100-m wide, 3-4-m deep channel meandering between sandy intertidal banks. Apart from these sand banks close to the mouth, intertidal areas are limited and depths are in the 3-5 m range along most of the longitudinal axis of the bay. Three main rivers flow into the system, the Morell and Midgell Rivers on the south shore and St Peter's River at the eastern end, draining a total catchment area of $280 \mathrm{~km}^{2}$.

In the early days of the PEI mussel farming industry in the 1980's, SPB was mostly used as a mussel seed collection area. Restrictions on seed transfers from bay to bay due to aquatic invasive species outbreaks in the late 1990's led to the reconversion of SPB into a grow-out site. At present, almost $40 \%$ of the bay area is dedicated to mussel culture as shown by the white polygons delineating the farms in Fig. 1. Mussels are grown in suspension using 1.8-m long polypropylene socks that hang from 100-m longlines typically submerged $1 \mathrm{~m}$ below the water surface. Longlines are lowered deeper into the water column during the winter months to avoid damage by a thick $(\sim 1 \mathrm{~m})$ ice cover from January to March (Environment Canada, http://www.ec.gc.ca/glaces-ice). Mussels usually spawn once in early or mid-May but have also been reported to spawn a second time during the fall (late September - early October; Smith and 
Ramsay 2012). Spring spat reach $20-30 \mathrm{~mm}$ in shell length by October at which time they are transferred to grow-out sites. Mussels reach an harvestable size of $55 \mathrm{~mm}$ shell length late in the fall of their second year ( $\sim 18$ mo mussels) but most of the harvest takes place the following spring up until June or July ( 24 mo mussels). Similarly as in Tracadie Bay (20 km west from SPB) where it was estimated to $2.8 \%$ of the cultured mussel biomass (Comeau et al. 2008) the wild mussel population in SPB is strongly limited by the lack of hard substrate. Wild mussels are then expected to play a marginal role in the ecosystem dynamics as well as in the production of seed for the mussel industry in St Peter's Bay and were not considered in the present study.

\subsection{Hydrodynamic model}

The present modelling work was carried out using the RMA10-RMA11 suite of finite element models (King 1982, King 2003). RMA10 is the hydrodynamic engine that solves the Reynolds form of the Navier-Stokes equations for momentum, the continuity equation and a convectiondiffusion equation for transport of heat, salinity and any dissolved or suspended matter. It uses a Smagorinsky scheme (Smagorinsky 1963) to estimate horizontal eddy diffusivities.

The model grid covers the whole of SPB, as well as a small portion of the GSL offshore from the mouth, and part of the three main river stretches in order to apply the open boundary conditions as far as possible from the inner bay processes.

A two-dimensional, vertically-averaged representation of the bay was thought to capture adequately the main features of its hydrodynamics. This shallow system is characterised by weak freshwater discharge and active wind mixing during the ice-free period. Moreover, vertical CTD profiles done in conjunction with the water sampling described in section 2.4.2 did not show any major vertical stratification in temperature and salinity except for short periods of time during the Fall and Spring when fresh water discharge is strongest. A weak gradient in salinity was observed along the main axis of SPB with mean values over the study period of $25.9 \pm 3.0,25.7$ $\pm 2.9,25.5 \pm 2.7$ and $24.3 \pm 3.4$ at stations SP1,2,3 and 4 (Fig. 1) respectively.

The spatial distribution of the e-folding water renewal time was estimated from the hydrodynamic model results and the convection-diffusion of a passive tracer in order to summarize the hydrodynamic behaviour of SPB and because it constitutes a strong driver of the spatial structure of coastal ecosystems (Filgueira et al. 2014). The details of the method may be found in Koutitonsky et al. (2004). Basically, bay waters are marked with a passive tracer (concentration $\mathrm{C}=1$ at $\mathrm{t}=0$ ) and the model reproduces the transport and renewal of these waters by tracer-free water $(\mathrm{C}=0)$ from the GSL and river input. Assuming an exponential decrease in concentration due to mixing, a given location within the bay is considered as renewed when the tracer concentration falls below $1 / \mathrm{e}$ of its initial value. The time taken to reach this state is defined as the water renewal time (Aubrey et al. 1993, Ranasinghe and Pattiaratchi 1998). 


\subsection{Biogeochemical model}

A detailed description of the biogeochemical structure is given by Guyondet et al. (2010). Only an overview will be presented here, with emphasis on the modifications implemented for the present application. Model equations and parameters are also outlined in Appendix A and B, respectively. The model describes the nitrogen cycle over the same grid as the hydrodynamic model and incorporates both a pelagic and a benthic compartment. Two forms of inorganic nutrients (ammonium: NH4 and nitrite-nitrate: NO3) support the primary production of the phytoplankton, which is represented by a single variable $(\mathrm{P})$. A zooplankton variable $(\mathrm{Z})$ feeds on $\mathrm{P}$ and organic detritus (D), which may be either re-mineralized or deposited on the bottom, completing the pelagic sub-model. The same single-layered benthic sub-model as in Guyondet et al. (2010) is used here to describe the organic matter recycling. Dissolved oxygen (O2) is represented both in the sediment and in the water column along with water temperature to account for their influence on various biochemical processes.

Water temperature is derived through a complete heat budget accounting for exchange with the atmosphere and also the production/melting of ice according to Larsen and Ashton (1986). The objective of the present work was not to accurately reproduce the dynamics of ice but rather to impose a realistic temperature cycle on the biogeochemical processes.

Cultured mussels are only included in the farm areas delineated by the polygons in Fig. 1, only the principal cohort (seeded the previous fall) is considered with a uniform and constant density $\mathrm{n}_{\mathrm{M}}=94$ ind $\mathrm{m}^{-2}$, based on sock numbers and socking density provided by the mussel growers and assuming that most of the fall-off and mortality occur within the first months after seeding. Their ecophysiology is reproduced using a dynamic energy budget (DEB, Kooijman 2000) set-up for M. edulis by Rosland et al. (2009). Mussels are allowed to feed on all kinds of organic matter (P, $\mathrm{Z}$ and D) with a different preference for each type. Mussels produce wastes either in dissolved form as ammonium or in particulate form as faeces that constitute the model biodeposit variable (BDP). Suspended particulate matter (SPM) concentrations in SPB remained low during most of the study period averaging $7.8 \mathrm{mg}$ dry weight $\mathrm{L}^{-1}$ for all inner stations combined. Apart from short term events most likely due to wind mixing SPM concentrations were close to the threshold for pseudofaeces production by M. edulis (4.5-5 mg dry weight $\mathrm{L}^{-1}$, Widdows et al. 1979). Consequently, pseudofaeces production does not seem to play an important role in SPB and was not included in the model.

All biogeochemical simulations presented here cover a full year cycle from June to June. Prior to that cycle, the model was given a 90-d spin-up period in order for the system to reach an equilibrium state. 


\subsection{Data collection}

\subsubsection{Hydrodynamics}

In order to force and calibrate the hydrodynamic model, tide gauges (Water Level Data Logger HOBO, Onset Computer Corporation Inc. Bourne, MA, USA) and a current meter (Workhorse Sentinel, Teledyne RD Instruments, Poway, CA, USA) were moored respectively at stations SPext, SP0, SP2b and SP4 (Fig. 1) during the summer of 2011 (June to August). Water level data collected at SPext were used to force the model while inner stations served as comparison points for model calibration. The tide gauge moored at SPext from August 2011 to April 2012 was unfortunately lost. In order to complete the forcing for a full year (June 2011-June 2012), the water level at SPext was derived from the tidal prediction obtained through harmonic analysis of the SPext tide gauge records (Foreman 1977) superimposed on the low-frequency fluctuations extracted, using a low-pass filter (Walters and Heston 1982), from the water level recorded at station Cap-aux-Meules located $100 \mathrm{~km}$ north of the study area (Canadian Hydrographic Service, http://www.tides.gc.ca/).

The tide gauges deployed at SPext were equipped with temperature sensors, providing temperature forcing for the June-August 2011 and April-June 2012 periods. The full year temperature cycle was completed using satellite SST data collected just outside SPB for the period September-November 2011 (NOAA-AVHRR, data produced by Fisheries and Oceans Canada and made available through the St. Lawrence Global Observatory, http://ogsl.ca/en/remotesensing/data.html). For winter months (December-March) the data used were collected the previous winter (2010-2011) using temperature loggers (MiniLog-T, VEMCO, Bedford, Nova Scotia, Canada) deployed at the same SPext station.

Meteorological data (air temperature, atmospheric pressure, wind speed and direction) were obtained from Environment Canada (St Peter's station, http://climat.meteo.gc.ca/). A meteorological station (Vantage Pro 2, Davis Instruments, Hayward, CA, USA) was also deployed at the end of Red Head wharf (Fig. 1) to monitor solar radiation. None of the three rivers included in the model were monitored for freshwater discharge during the study period. Discharges were instead derived from observations made for Winter River (Environment Canada station $01 \mathrm{CC} 002,25 \mathrm{~km}$ west of the study area) by applying the corresponding watershed area ratios.

\subsubsection{Biochemical characteristics}

Water sampling was carried out biweekly during the ice-free season from June 2011 to June 2012 at 5 stations (SPext and SP1,2,3,4; Fig. 1). Two water samples ( $0.5 \mathrm{~m}$ below the surface and $0.5 \mathrm{~m}$ above the bottom) were collected at each station and analyzed for suspended particulate matter (SPM), particulate organic matter (POM), POM composition, inorganic nutrients and phytoplankton following the methods described in Table 1. Organic detritus concentrations were calculated using the nitrogen content of POM from which the converted 
phytoplankton biomass was subtracted (Chl a/C $=1 / 50$ (Claustre et al. 1994) and N/C = 16/106

Redfield molar ratio (Redfield 1934)). For all variables, surface and bottom concentrations were pooled to give vertically-averaged values which were used to force and calibrate the model.

Observations at SPext were linearly interpolated between dates to build the off-shore boundary conditions. River conditions were derived in the same way using observations at the closest station, except for nitrate levels that were represented by the climatology data compiled for Morell River by Raymond et al. (2002) from a monitoring program conducted by the PEI Department of Environment, Labour and Justice.

Because insufficient data were available on ammonium and zooplankton to build time-varying open boundary conditions, these conditions were kept constant at NH4 $=16.8 \mathrm{mg} \mathrm{N} \mathrm{m}^{-3}$ and Z $=$ $20 \mathrm{mg} \mathrm{C} \mathrm{m}^{-3}$, levels typically observed in the region (Guyondet et al. 2010, PEI Department of Environment, Labour and Justice monitoring http://www.gov.pe.ca/envengfor/waterdata, Trottet et al. 2007). Moreover, model results (mussel production) did not show any particular sensitivity to changes in these boundary values (maximum of $\pm 0.5 \%$ for a $\pm 10 \%$ change in boundary value).

\subsubsection{Mussel growth}

During the ice-free season between June 2011 and June 2012, a 30-cm section of mussel sock was collected monthly from a single commercial longline near station SP2. A subsample of at least 50 mussels was randomly selected for measurements of shell length (to the nearest 0.01 $\mathrm{mm}$ ) and meat dry weight (after desiccation at $70{ }^{\circ} \mathrm{C}$ for $24 \mathrm{~h}$ ).

\subsection{Model Calibration}

\subsubsection{Hydrodynamic model}

The only parameter of the hydrodynamic model to be calibrated was the bottom friction scaled by a unique Manning coefficient (n) over the whole domain. The calibration was based on the comparison of observed and model-predicted water levels and currents at inner stations SP0, SP2b and SP4 over the June-August 2011 period. For this calibration run the model imposed a full set of natural forcing: offshore water level (observed at SPext), atmospheric forcing and river discharges from the sources mentioned above.

\subsubsection{Biogeochemical model}

As the previous version of this model was developed for a similar environment (Guyondet et al. 2010), the set of parameters considered in the calibration process was kept to a minimum. Phytoplankton and zooplankton were the most modified variables as each was split into two size classes in the previous model. Zooplankton was given the attributes of the former mesozooplakton variable and its food preference coefficients were slightly adjusted to account for the reduced number of available prey items. The parameters of the new phytoplankton variable were adapted to represent the dynamics of a mixture of pico- and nano-phytoplankton. 
The updated values of the parameters are given in Appendix B along with the parameters of unchanged variables. The whole calibration process was based on minimizing the cost function $\left(C_{x}\right.$, Radach and Moll 2006, Villars et al. 1998) that describes the discrepancy between observed and predicted variables as follows:

$$
C_{x}=\frac{1}{2} \frac{\frac{1}{n} \sum_{i=1}^{n}\left|M_{x, i}-D_{x, i}\right|}{s d_{x}}+\frac{1}{2}\left(1-r_{x}\right)
$$

where $M_{x, i}$ and $D_{x, i}$ are the predicted and observed variable values at station $x$ and date $i$, respectively, $\mathrm{n}$ is the number of comparison dates, $\mathrm{sd}_{\mathrm{x}}$ is the standard deviation of observed data at station $\mathrm{x}$ over the entire comparison period, and $r_{x}$ is the correlation coefficient between the predicted and observed time series over the entire comparison period. $\mathrm{C}_{\mathrm{x}}$ is expressed in standard deviation units. For $\mathrm{C}_{\mathrm{x}}<1,1 \leq \mathrm{C}_{\mathrm{x}}<2,2 \leq \mathrm{C}_{\mathrm{x}}<3$ and $\mathrm{C}_{\mathrm{x}}>3$, model results are respectively considered very good, good, reasonable and poor (Radach and Moll 2006). This cost function was estimated for each pelagic variable for which observed data were available and at inner stations SP1,2,3,4.

\subsubsection{DEB ecophysiological model}

The mussel DEB structure was left unchanged from Rosland et al. (2009). For the coupling with the ecosystem model, mussel food preferences were slightly adjusted in the same way as for zooplankton. Two DEB parameters were adapted respectively to the studied population (shape coefficient, $\delta$ ) and site conditions (food half saturation coefficient, $\mathrm{K}_{\mathrm{F}}^{\mathrm{M}}$ ). The shape coefficient relates the shell length $(\mathrm{L}, \mathrm{cm})$ to the structural volume $\left(\mathrm{V}, \mathrm{cm}^{3}\right)$ of the mussels as follows:

$$
\delta=\frac{\mathrm{V}^{1 / 3}}{\mathrm{~L}}
$$

This parameter was estimated from measurements of shell length and dry meat weight of 90 mussels collected from socks in November 2010 just before they were deployed at the grow-out site. The dry meat weight (DW) observations were converted to volume using a dry to wet weight ratio of 0.2 and a wet weight to volume ratio of $1 \mathrm{~g} \mathrm{~cm}^{-3}$. Mussel meat not only contains structural tissues but energy reserves and gonads as well. Hence, the method described in Rosland et al. (2009) was used to adjust $\delta$ so that only $5 \%$ of observations fall below the volumelength curve described by Eq. 2 .

The calibration of the remaining mussel model parameter $\mathrm{K}_{\mathrm{F}}^{\mathrm{M}}$ was conducted within the coupled model framework by comparing observed and predicted data of individual shell length and dry meat weight at station SP2. 


\subsection{Scenarios}

In order to study the effects of past nutrient input increase and future environmental forcing, two working scenarios were developed in addition to the base scenario which reproduced the system under the conditions observed in 2011-2012. The three scenarios cover the same annual cycle from June to June. The past scenario is meant to represent the system in 1980 at the onset of commercial mussel culture while the future scenario reproduces environmental conditions predicted for the year 2050. Precipitation, temperature and river nutrient levels were the only parameters manipulated to build these scenarios; modifications are reported in Table 2 and detailed below. In combination with the above scenarios, mussel stocking density was also manipulated to investigate the effects of the shellfish culture activity under different environmental conditions.

Precipitation is predicted to increase by $10 \%$ in 2050 (Vasseur and Catto 2008). This increase was directly applied to river discharges in the 2050 model. River discharge/precipitation in the 1980 scenario were maintained at baseline levels.

Due to land-use changes nitrate concentrations in Morell River have doubled since the 1980's (Raymond et al. 2002); nitrate concentrations were therefore reduced accordingly in all rivers for the 1980 scenario. The PEI government is taking action to restrain nutrient loading to aquatic systems through various initiatives such as the Agriculture Stewardship Program and the Alternative Land Use Services (PEI Department of Agriculture and Forestry, http://www.gov.pe.ca/growingforward). Consequently, it was assumed that no further increase in river nutrient levels would occur so 2011 baseline concentrations were used in the 2050 scenario.

According to Vasseur and Catto (2008) annual mean air temperature increased by $0.3{ }^{\circ} \mathrm{C}$ between 1948 and 2005 , but is predicted to increase by $4{ }^{\circ} \mathrm{C}$ by 2050 with a slightly stronger increase in winter compared to the rest of the year. Based on these observations / predictions air temperatures were left unchanged in the 1980 model while 2050 temperatures were uniformly increased by $4{ }^{\circ} \mathrm{C}$ in the heat budget calculation and ice-cover prediction.

Regarding water temperature forcing, a sinusoidal curve was fitted to the annual cycle obtained for 2011-2012 as described in section 2.4.1. This seasonal trend was then modified to construct the 1980 and 2050 boundary forcing according to Sea Surface Temperature (SST) observations made by Taboada and Anadón (2012). These authors compiled SST data for the GSL over the period 1982-2010 and reported an increase of $0.3-0.4{ }^{\circ} \mathrm{C}$ decade ${ }^{-1}$ in the annual mean with an acceleration of this trend over time. They also noted a much stronger increase (about 6 fold) in the seasonal maxima than in the minima, and no change in the timing of the seasonal maxima but a change in the seasonal minima occurring earlier by $6-8 \mathrm{~d} \mathrm{decade}^{-1}$. These trends were used to derive the 1980 and 2050 seasonal cycles as summarized in Table 2. The de-trended 2011-2012 water temperature series was then imposed on the constructed seasonal cycles to produce the boundary forcing conditions for both scenarios shown in Fig. 2. 


\section{RESULTS AND DISCUSSION}

\subsection{Model calibration}

\subsubsection{Hydrodynamics}

Observations and model predictions were generally in good agreement for a Manning coefficient of $n=0.026$. As shown in Fig. 3 for the month of July 2011, the model reproduces quite accurately both the timing and range of water level and current velocity time series at the different stations inside SPB. Quantitatively, harmonic analysis results (Table 3) show a very good agreement between the observed and predicted tidal signals. All forcing considered, the model is able to predict over $85 \%$ of the total variance in water level fluctuations at all inner stations (Table 3). Overall the model appears to represent accurately the inner bay hydrodynamics and its exchange with the GSL, and may thus be coupled with the biogeochemical structure to investigate SPB ecosystem dynamics.

\subsubsection{Biogeochemistry}

Table 4 summarizes the comparison of observed and model-predicted biochemical variables at all inner stations expressed by the cost function. Based on this metric, model results can be considered as "very good" or "good" for all stations/variables, except for P at station SP1 where the cost function is slightly above 2 , indicating a "reasonable" result quality. As might be expected model results are better for driving variables such as temperature and NO3 than for P and $\mathrm{D}$. The prediction of the latter variables depends on the former which make $\mathrm{P}$ and $\mathrm{D}$ more prone to error accumulation. However, model results (mussel production) did not show any particular sensitivity to changes in $\mathrm{P}$ and $\mathrm{D}$ concentrations (maximum of $\pm 3.6 \%$ change for a $\pm 10 \%$ change in $\mathrm{P}$ or $\mathrm{D}$ forcing).

No data was available to ascertain the validity of model results during the ice-covered and spring bloom periods. However, the expected minimum activity during the ice-covered period and the short duration of the spring bloom period (less than one month between ice break-up and first data point) constrain their effects on the overall uncertainty of the model.

An example of the consistency between observations and model results is given in Fig. 4 for station SP2. Water temperature is well reproduced by the model during the ice-free season. Data recorded by a temperature logger moored at SP2 in winter-spring 2010-2011 was also included in Fig. 4a. The comparison of this time series with model results shows that despite the use of default parameters for the ice module of RMA, the model also represents an acceptable temperature forcing during the ice season.

The seasonal cycle of NO3 concentration is well reproduced by the model with low concentrations in summer and an accumulation during the biologically inactive winter period (Fig. 4b). No observations were available to validate the timing and rate of utilization and 
depletion by primary producers in spring. However, predicted concentrations drop back down to observed levels in May-June 2012.

The model reproduces $\mathrm{P}$ biomass accurately during summer and fall. Predictions at the end of the simulated period (May-June 2012), however, seem to overestimate P, although no data are available during the spring bloom period to verify this conclusion. The predicted timing of the spring bloom (Fig. 4c) corresponds well with an 8-d frequency series of Chlorophyll $a$ derived from satellite observations made just off-shore of SPB (4 km MODIS-Aqua, Giovanni online data system, NASA GESDISC, http://disc.sci.gsfc.nasa.gov/giovanni). The spring overestimation of $\mathrm{P}$ may be explained by the model accounting only for primary production associated with phytoplankton. In reality, macrophytes are probably using part of the nutrients accumulated during winter thus reducing the quantity available to phytoplankton.

Phytoplankton primary production rates simulated by the coupled model (November: $41 \mathrm{mg} \mathrm{C}$ $\mathrm{m}^{-2} \mathrm{~d}^{-1}$, June/July: $\left.340 \mathrm{mg} \mathrm{C} \mathrm{m}^{-2} \mathrm{~d}^{-1}\right)$ are also in general accordance with observations $\left({ }^{14} \mathrm{C}\right.$ incubations, JGOFS 1994) made on several occasions in SPB in 2011-2012; these values ranged from $55.2 \mathrm{mg} \mathrm{m}^{-2} \mathrm{~d}^{-1}$ in November 2011 to $415 \mathrm{mg} \mathrm{C} \mathrm{m}^{-2} \mathrm{~d}^{-1}$ in July 2011.

The predicted levels of D are generally lower than those observed (Fig. 4d), except for a slight overestimation in spring, probably due to the same uncertainty in estimating P. This apparent underestimation may be due to the model not accounting for different sources of organic detritus, such as terrestrial inputs and aquatic macrophytes, while observed values (calculated by subtracting the phytoplankton biomass from the total organic particulate matter) include all kinds of detritus.

There was no validation data available for zooplankton in SPB. However, zooplankton biomass predicted by the model varied between $3.7 \mathrm{mg} \mathrm{C} \mathrm{m}^{-3}$ under the ice-cover during winter months and $69.3 \mathrm{mg} \mathrm{C} \mathrm{m}^{-3}$ during summer which is in agreement with reported values in the southern Gulf of Saint-Lawrence during the ice-free period (28 - $171 \mathrm{mg} \mathrm{C} \mathrm{m}^{-3}$, Savenkoff et al. 2000).

Finally, given that mussels integrate the fluctuations of environmental conditions over time, they provide a valuable groundtruthing of model results (Filgueira et al. 2013). Moreover, cultured mussels are the focus of the present study hence; the model is required to perform well on that aspect. Mussel growth is very well reproduced by the DEB coupled to the biogeochemical model, both in terms of shell length and tissue weight (Table 4, Fig. 4e and f). The timing of both spawning events (end of September and mid-May), represented by drops in the predicted tissue weight in Fig 4f, matches well with data from local surveys (Smith and Ramsay 2012). 


\subsection{Current conditions in SPB (scenario 2011)}

\subsubsection{Hydrodynamics}

Figure 5 presents the spatial distribution of water renewal time over SPB due to tidal and freshwater forcing. Tidal forcing from the GSL is weak with a range of 0.3 to $0.7 \mathrm{~m}$ in neap and spring conditions, respectively (Fig. 3). Its influence on the renewal of SPB waters rapidly decreases over the outer third of the bay. A sharp increase in renewal time can be seen towards the middle part of SPB, reaching values exceeding 80 days at the head. Apart from its outer section where strong tidal currents (close to $1 \mathrm{~m} \mathrm{~s}^{-1}$ at SP0, Fig. 3) occur in the narrow channel connecting the bay with the GSL, most of SPB is characterized by poor flushing with tidal currents of a few centimeters per second.

\subsubsection{Level of mussel culture}

In order to estimate the magnitude of changes in modelled variables and processes due to aquaculture, the current conditions simulation (2011) was compared to a simulation with identical environmental forcing but without mussel farms. The results of this comparison are presented as the relative change in the annual mean of the variable or process of interest, with negative values corresponding to a decrease when cultured mussels are introduced into the system ( Change in $\mathrm{X}=100 \times \frac{X_{\text {Mussel }}-X_{\text {NoMussel }}}{X_{\text {NoMussel }}}$ ). Figure 6 shows maps of the spatial distribution of this mean annual change for the main model variables. As expected from the spatial extent of the farmed area, cultured mussels affect most of SPB.

$\mathrm{Z}$ biomass is the variable most affected by the introduction of mussels, but this result might be an artifact of the model structure. In the simulation with no mussels present, the situation is unrealistic in that zooplankton becomes the only grazer with no competition. Hence, $\mathrm{Z}$ biomass may be exaggerated, which in turn leads to an overestimation of mussel farming effects when this biomass is compared to levels observed in presence of aquaculture. Although no data are available to quantitatively assess the validity of this model result, this comparison nonetheless underlines the potential negative impact of cultured mussels on zooplankton both as competitors and by directly feeding on part of its biomass (Lehane and Davenport 2006, Maar et al. 2008).

The two main food sources for mussels, phytoplankton (P) and organic detritus (D), show similar depletion patterns (Fig. 6) with maximum aquaculture effects evident in the central part of the bay. Both ends of the SPB system act as food reservoirs, due to rapid water renewal at the mouth, and increased primary production due to slow water renewal, river nutrient inputs and absence of farms at the head. In this context, the reversing tidal currents lead to the average $P$ and D distribution shown in Fig. 6 with maximum food depletion in the central region, which at any tidal stage receives water that has already flowed through farmed areas. Similar depletion patterns have already been observed or predicted at smaller spatial scales of mussel longlines and rafts (Petersen et al. 2008, Rosland et al. 2011, Strohmeier et al. 2008). In the case of SPB, the 
simulation suggests that the whole system behaves as a single large mussel farm. Bay-scale depletion has also been reported in a neighbouring inlet, Tracadie Bay which supports a similar level of mussel aquaculture development (Grant et al. 2008). D depletion reaches higher levels than $\mathrm{P}$ depletion, as this latter component of the system has the ability to renew itself through primary production, and directly benefits from the positive feedback of mussels on nutrient availability through $\mathrm{NH} 4$ excretion.

Evidence of this feedback mechanism is corroborated by the increase in NH4 concentration over $2 / 3$ of SPB in the presence of mussel aquaculture (Fig. 6). However, predictions of NH4 depletion in the inner bay suggest that in this area the mussel feedback loop is overwhelmed by the conjunction of increased primary production as shown in Fig .7 (upper panel), decreased D recycling due to $\mathrm{D}$ depletion, and decreased $\mathrm{Z}$ excretion due to $\mathrm{Z}$ depletion. The net balance of these processes also depends on the water renewal rate which sets the time scale for each mechanism to influence the averaged conditions. Based on Fig. 7 (upper panel), two distinct areas of SPB experience conditions that promote the positive feedback of mussels on phytoplankton production.

Besides these pelagic effects, shellfish aquaculture is also known to increase sedimentation fluxes in farmed areas due to the compaction of large amounts of small suspended particles into larger, heavier faecal pellets through filtration, ingestion and digestion (Cranford et al. 2009, Giles and Pilditch 2006, McKindsey et al. 2011, Newell 2004). The model results show that the introduction of mussel aquaculture in SPB completely disrupts the sedimentation pattern (very limited area with $0 \%$ change in Fig. 7, bottom panel). However, increases in sedimentation are limited to $10-15 \%$ and confined to the central zone of the larger farmed areas, and to the outer parts of the bay where natural sedimentation is lower due to the faster flushing/stronger tidal currents. When integrated over the whole SPB, sedimentation rates actually decrease by $14 \%$ in the presence of cultured mussels, which is logical given that mussels assimilate an important fraction of the particulate organic matter (POM) they consume. Figure 7 (bottom panel) also illustrates the difficulty in making unbiased field observations of the effects of shellfish aquaculture on sedimentation rates as the footprint of this activity may extend far beyond the confines of the farm (Cranford et al. 2009).

In order to further illustrate alterations in the SPB system due to mussel aquaculture, the mussel stock was incremented from no mussels (NoM), to $1 / 4$ of the present stock $\left(n_{M} / 4\right), 1 / 2$ of the present stock $\left(n_{M} / 2\right)$, the present stock $\left(n_{M}\right)$ and twice the present stock $\left(n_{M} \times 2\right)$. Results are presented as the annual mean estimate for each variable, integrated over the whole SPB (Fig. 8). All variables showed a marked trend with increasing mussel stock, decreasing for $\mathrm{P}, \mathrm{D}$ and $\mathrm{Z}$, and increasing for dissolved inorganic nitrogen ( $\mathrm{DIN}=\mathrm{NH} 4+\mathrm{NO} 3)$, thus confirming the bayscale effect of aquaculture activity. It should be noted that annually-averaged values may obscure some of the mussel-system interactions, especially in the case of DIN and P whose dynamics are characterized by strong seasonal highs in winter and spring, respectively. 
Figure 9 displays time series of DIN and P concentrations integrated over SPB for the different mussel stocking densities. As mussel stock increases, DIN dynamics are mainly affected in the fall with an earlier and steeper build-up at the end of the productive season. This leads to increased concentrations over winter that account for the relatively high annual mean values mentioned earlier. Mussel culture effects on P can be seen both during fall (October-November) and spring (April-May). The fall bloom, although weak in intensity and probably not greatly affecting the $\mathrm{P}$ annual mean, is completely suppressed at high mussel stocking densities $\left(\mathrm{n}_{\mathrm{M}}\right.$ and $\mathrm{n}_{\mathrm{M}} \times 2$ ). The effect of mussel culture in spring is evident in the reduction in bloom intensity and duration; this explains an important part of the decreasing trend in annual mean $\mathrm{P}$ values with increasing mussel stock.

As stated by Asmus and Asmus (1991), the positive feedback of mussels on P through NH4 excretion may only be effective during periods of nutrient limitation. The present model results lead to the same conclusion over the summer (Fig. 8b, summer 2011). When averaged only over the summer (June-August 2011), which is likely the main period of nutrient limitation, $\mathrm{P}$ concentrations integrated over SPB actually increase with increasing mussel stock, up to current conditions $\left(\mathrm{n}_{\mathrm{M}}=94\right.$ ind $\left.\mathrm{m}^{-2}\right)$. On an annual cycle, this effect is overridden by the grazing on $\mathrm{P}$ during the spring bloom period. This variable relationship highlights the need to include the whole productive period in the study of the interactions between cultured shellfish and coastal ecosystems.

The model results provide several clues about the production and ecological carrying capacity of the SPB ecosystem for mussel farming activity. First, the positive feedback mechanism just mentioned seems to be overridden by $\mathrm{P}$ depletion when the mussel stock is increased above the current value ( $\mathrm{n}_{\mathrm{M}} \times 2$, Fig. 8b, summer 2011). Moreover, at this very high stocking level, mussel excretion becomes the main pelagic DIN recycling pathway on an annual basis and at the scale of the whole SPB (Fig. 10d). Finally, at the current stocking level and beyond, the fraction of phytoplankton primary production grazed by cultured mussels exceeds $70 \%$. These latter results indicate that the system is approaching the ultimate production capacity, defined by Gibbs (2004) as the state where the matter/energy cycle is reduced to N-P-D-Mussels and nothing is left to be transferred to higher pelagic trophic levels through zooplankton. Overall, SPB seems to have reached its ecological carrying capacity for mussel aquaculture at the current stocking level.

\subsection{Effects of river nutrient inputs (scenario 1980)}

Comparing model results for the 1980 and 2011 conditions primarily provides insight into the effects of increased nitrogen $(\mathrm{N})$ loading; water temperatures within SPB only increased by 0.4 ${ }^{\circ} \mathrm{C}$ between the two scenarios (RMSD on an annual cycle between temperatures integrated over SPB). The 50\% increase in N inputs between 1980 and 2011 caused some of the greatest changes in DIN concentration and $\mathrm{P}$ biomass observed in the various scenarios reproduced in the present study (Fig. 8a and b). As reported in many coastal systems (Cloern 2001, Nixon 1995, Rosenberg 1985, Smith 2006), additional DIN fuels an increase in net primary production (Fig. 
$10 a)$, in this case amounting to a $20-30 \%$ increase. This additional production in turn benefits higher trophic levels as shown by the increase in grazing rates on P (Fig. 10b), Z biomass (Fig. 8d) and growth of cultured mussels (Fig. 4e and f).

In recent years, bivalve aquaculture has been proposed as a bioremediation measure to counter the increase in nutrient loading in coastal areas (Carmichael et al. 2012, Ferreira et al. 2007, Gifford et al. 2005, Higgins et al. 2011, Lindahl et al. 2005, Petersen et al. 2014). The SPB model results indicate that on an annual basis net mussel meat production represents a potential $\mathrm{N}$ harvest equivalent to $42 \%$ of river inputs or $46.5 \%$ of the net phytoplankton primary production under current conditions $\left(2011, \mathrm{n}_{\mathrm{M}}=94 \mathrm{ind}^{-2}\right)$. Consequences of this important mitigation process can also be seen in $\mathrm{P}$ biomass that under current conditions is similar to 1980 's levels when aquaculture was not developed $\left(\mathrm{n}_{\mathrm{M}}=0\right.$ ind $\left.\mathrm{m}^{-2}\right)$ and $\mathrm{N}$ loads were half as high (Fig. 8b).

Other primary producers may also have benefited from the combined effects of mussel aquaculture and $\mathrm{N}$ loading. Although it is difficult to predict the response of ecosystem components not included in the model, known interactions can be invoked here. The distribution and production of seagrass meadows (Zostera marina), common in the area, are generally thought to be light-limited (Peterson and Heck 1999, Twilley et al. 1985). The increased light availability associated with the decrease in POM concentration (P and D, Fig. 8a and b) due to cultured mussel filtration, likely enhances the growth of benthic vegetation, as has been noted in other regions and mesocosm studies (Phelps 1994, Wall et al. 2011). On the other hand, macroalgae are often nutrient-limited, especially the free-floating species (Valiela et al. 1997). These producers could potentially take advantage of the elevated DIN levels projected by the model, even in presence of bivalve culture (Fig. 8a). Reports of sea lettuce (Ulva lactuca) blooms and anoxic events in recent years in various locations in Prince Edward Island, and in the Morell River in particular (Danielescu and MacQuarrie 2011, Raymond et al. 2002), support the suggestion that mussel aquaculture does not prevent localized eutrophication events.

In the particular case of PEI where mussel aquaculture development occurred simultaneously with the increase in land-derived DIN inputs to coastal systems, a reduction in these inputs could potentially be detrimental to the mussel industry (Cranford et al. 2007). In SPB, if the DIN inputs were to decline to 1980 's levels, the model predicts that mussel production would experience a $13 \%$ reduction.

\subsection{Effects of temperature increase (scenario 2050)}

The climate change scenario tested here differs from the current conditions (2011) mainly with regard to temperature forcing, but also includes a $10 \%$ increase in nutrient inputs due to higher precipitation. The main effect of the temperature increase is an acceleration in the overall system metabolism as revealed by the higher values reported for all rates in Fig. 10. The net effect of this acceleration seems to be a stronger top-down control of phytoplankton levels with $\mathrm{P}$ 
concentrations reduced to close to 1980's levels but DIN slightly higher than in 2011 (Fig. 8a and $b$ ). This may result from primary production not being only controlled by temperature and DIN but by light availability as well. Although temperature and DIN limitations are alleviated the remaining limitation by light combined with the increased zooplankton and mussel grazing rates lead to the increased top-down control predicted by the model. Again this P decrease and DIN increase may amplify the risk of eutrophication, especially in warmer waters that have a lower dissolved oxygen capacity.

Under these future conditions, the model predicts a $30 \%$ increase in mussel production if the current stocking density $\left(\mathrm{n}_{\mathrm{M}}=94\right.$ ind $\left.\mathrm{m}^{-2}\right)$ is maintained. This gain is mainly due to the better utilization of the phytoplankton spring bloom in warmer water; this allows the mussels to spawn earlier in the spring (Fig. 4f) and recover more rapidly from this weight loss, thus reaching a much higher weight in early June at the end of the simulation period. This result is in contrast with the $70 \%$ decrease in mussel production predicted in an Irish Sea lough for a similar warming scenario $\left(+4{ }^{\circ} \mathrm{C}\right.$; Ferreira et al. 2008). Although no details were provided, summer temperatures may have reached values high enough to cause deleterious effects on the mussels in their area. Ferreira et al. (2008) did not include any nutrient loading increase in their scenario but the $10 \%$ increase included in the present study would probably not explain the major discrepancy between the two assessments. These opposing trends might rather follow from a difference in average temperature conditions between the two systems, with temperatures presumably colder in PEI than in Ireland. Mussels in Strangford Lough may then be closer to their optimum temperature range in present conditions which would explain the decrease in production in the warmer scenario. This comparison highlights the attention that should be paid to the description of temperature effects on physiological processes for future climate change impact modelling.

In SPB, our model predicts water temperatures in excess of $25^{\circ} \mathrm{C}$ during the warm summer scenario. At such temperatures mussel physiological processes such as the filtration rate may be depressed (Schulte 1975, Theede 1963). Consequently, starting in early July and extending into early September, the DEB model predicts negative temperature impacts with depressions in mussel physiological rates up to 50\% compared to summer 2011 . This explains, at least in part, the delayed fall spawning predicted by the model in the 2050 scenario (Fig. 4f). A more comprehensive assessment of the effects of these stressful high summer temperatures would necessitate incorporating the probability of increased summer mortality rates (Mallet et al. 1990, Myrand et al. 2000), which would minimize the $30 \%$ production increase predicted a priori.

Finally, the 2050 model results show signs of a slight increase in both the production and ecological carrying capacity of SPB. In particular, this increase in mussel production does not come at the expense of other consumers as the fraction of primary production grazed by mussels is actually reduced by $5 \%$ for current stocking density $\left(\mathrm{n}_{\mathrm{M}}=94\right.$ ind $\left.\mathrm{m}^{-2}\right)$. However, increasing mussel stocks beyond present day levels would again tighten the energy cycle of this coastal 
system to the advantage of cultured mussels, leaving few resources behind for higher trophic levels, a situation that may be characterized as exceeding ecological carrying capacity.

\section{CONCLUSION}

The model implemented in the present study allowed for the examination of coastal system dynamics under the combined effects of different pressures, i.e. bivalve aquaculture, nutrient loading and climate change. It is suggested that intense mussel culture in SPB plays an important role in remediating land-derived nutrient loading. Nonetheless, it seems that intensive mussel culture does not prevent the development of eutrophication symptoms, especially when associated with very specific, local conditions such as macroalgae blooms. Further investigation and model development are needed to better understand the contribution of cultured shellfish in the relative distribution of primary production between phytoplankton, macroalgae and benthic macrophytes.

The climate change scenario was based on up-to-date predictions of climate evolution at the regional scale. Under such conditions the model predicted an increase in both the production and ecological carrying capacity of SPB for mussel aquaculture. However this prediction assumed that summer maximum temperatures would not cause widespread mortality events. A potential amplification of eutrophication symptoms was also identified. Such investigations of potential effects of climate change are crucial for our adaptive management of coastal ecosystem resources and services.

The intensity of bivalve aquaculture effects on coastal ecosystems is strongly site dependent and is tightly linked to the level of aquaculture development and the water renewal rate. SPB aquaculture development level, expressed as total bay area coverage, is among the highest compared to other major bivalve production areas around the world (Table 5). Moreover, SPB is a semi-enclosed system characterised by restricted exchange with the open ocean. Consequently, the results obtained in the present study are likely to lie at the upper end on the scale of bivalve culture influence on coastal ecosystems, especially in terms of potential for nutrient loading mitigation and sensibility to increased temperature forcing.

The combined influence of various pressures observed in this study confirms the need for an ecosystem-based approach to bivalve aquaculture and coastal resources management and the utility of numerical modelling to provide relevant information for this process. 


\section{ACKNOWLEDGEMENTS}

This project was funded by DFO's Program for Aquaculture Regulatory Research (PARR project 2010-G-06). The authors gratefully acknowledge Thomas Landry and Arthur Smith for their input and advice during the initial phases of the project. Thanks are also due to mussel growers for their cooperation. Stephen Fortune generously contributed his time, boat, and kindly allowed our team to work inside his lease. Tina Sonier, André Nadeau, Liliane St-Amand and Roxanne Girard provided invaluable technical assistance during the 16 field expeditions. 


\section{REFERENCES}

Alvarez-Salgado, X.A., G. Roson, F.F. Perez, F.G. Figueiras, and Y. Pazos. 1996. Nitrogen cycling in an estuarine upwelling system, the Ria de Arousa (NW Spain). I. Short-timescale patterns of hydrodynamic and biogeochemical circulation. Marine Ecology Progress Series 135: 259-273.

Aminot, A. 1983. Mesure des matières en suspension. In Manuel des analyses chimiques en milieu marin., ed. A. Aminot and M. Chaussepied, 169-175. Brest, France: Centre national pour l'exploitation des océans.

Ariathurai, R., and R.B. Krone. 1976. Finite element model for cohesive sediment transport. Journal of the Hydraulics Division, ASCE 102: 323-338.

Asmus, R.M., and H. Asmus. 1991. Mussel beds: limiting or promoting phytoplankton? Journal of Experimental Marine Biology and Ecology 148: 215-232.

Aubrey, D.G., T.R. McSherry, and P.P. Eliet. 1993. Effects of multiple inlet morphology on tidal exchange: Waquoit Bay, Massachussetts. In Formation and evolution of multiple tidal inlets. Coastal and Estuarine studies, ed. D.G. Aubrey and G.S. Giese, 213-235. Washington D.C.: American Geophysical Union.

Bacher, C., B. Millet, and A. Vaquer. 1997. Modelling the impact of cultivated filter-feeders on phytoplanktonic biomass of the Thau Lagoon (France). Comptes Rendus de l'Academie des Sciences, Serie III. Sciences de la Vie/Life Sciences 320: 73-81.

Banas, N.S., and B.M. Hickey. 2005. Mapping exchange and residence time in a model of Willapa Bay, Washington, a branching, macrotidal estuary. Journal of Geophysical Research: Oceans 110: C11011.

Baretta-Bekker, J.G., J.W. Baretta, and E.K. Rasmussen. 1995. The microbial food web in the European regional seas ecosystem model. Netherlands Journal of Sea Research 33: 363379.

Bayne, B.L. 1976. The biology of mussel larvae. In Marine mussels: their ecology and physiology, ed. B.L. Bayne, 81-120. Cambridge: Cambridge University Press.

Bayne, B.L., and R.C. Newell. 1983. Physiological energetics of marine molluscs. In The Mollusca, Vol. 4, Physiology, ed. A.S.M. Saleudin and K.M. Wilber, 407-515. New York: Academic Press.

Beaulieu, S.E. 2003. Resuspension of phytodetritus from the sea floor: A laboratory flume study. Limnology and Oceanography 48: 1235-1244.

Bergamasco, A., and C. Zago. 1999. Exploring the nitrogen cycle and macroalgae dynamics in the Lagoon of Venice using a multibox model. Estuarine, Coastal and Shelf Science 48: 155-175.

Boudreau, B.P. 1996. A method-of-lines code for carbon and nutrient diagenesis in aquatic sediments. Computers \& Geosciences 22: 479-496.

Bougis, P. 1976. Marine plankton ecology. North-Holland, Amsterdam.

Brigolin, D., G. Dal Maschio, F. Rampazzo, M. Giani, and R. Pastres. 2009. An individual-based population dynamic model for estimating biomass yield and nutrient fluxes through an offshore mussel (Mytilus galloprovincialis) farm. Estuarine, Coastal and Shelf Science 82: 365-376.

Byron, C., D. Bengtson, B. Costa-Pierce, and J. Calanni. 2011a. Integrating science into management: Ecological carrying capacity of bivalve shellfish aquaculture. Marine Policy 35: 363-370. 
Byron, C., J. Link, B. Costa-Pierce, and D. Bengtson. 2011b. Modeling ecological carrying capacity of shellfish aquaculture in highly flushed temperate lagoons. Aquaculture 314: 8799.

Cairns, D.K. 2002. Land use and aquatic resources of Prince Edward Island streams and estuaries: an introduction. In Effects of land use practices on fish, shellfish, and their habitats on Prince Edward Island, ed. D.K. Cairns, 1-13. Ottawa, Canada: Canadian Technical Report of Fisheries and Aquatic Sciences. No. 2408.

Callier, M.D., A.M. Weise, C.W. McKindsey, and G. Desrosiers. 2006. Sedimentation rates in a suspended mussel farm (Great-Entry Lagoon, Canada): biodeposit production and dispersion. Marine Ecology Progress Series 322: 129-141.

Carmichael, R.H., W. Walton, and H. Clark. 2012. Bivalve-enhanced nitrogen removal from coastal estuaries. Canadian Journal of Fisheries and Aquatic Sciences 69: 1131-1149.

Cerco, C.F., and T.M. Cole. 1994. Three-dimensional model of Cheasapeake Bay. Vicksburg, MS: US Army Corps of Engineers Technical Report EL-94-4.

Chapelle, A. 1995. A preliminary model of nutrient cycling in sediments of a Mediterranean lagoon. Ecological Modelling 80: 131-147.

Chapelle, A., P. Lazure, and A. Ménesguen. 1994. Modelling eutrophication events in a coastal ecosystem. Sensitivity analysis. Estuarine, Coastal and Shelf Science 39: 529-548.

Chapelle, A., A. Menesguen, J.-M. Deslous-Paoli, P. Souchu, N. Mazouni, A. Vaquer, and B. Millet. 2000. Modelling nitrogen, primary production and oxygen in a Mediterranean lagoon. Impact of oyster farming and inputs from the watershed. Ecological Modelling 127: $161-181$.

Christensen, P.B., R.N. Glud, T. Dalsgaard, and P. Gillespie. 2003. Impacts of longline mussel farming on oxygen and nitrogen dynamics and biological communities of coastal sediments. Aquaculture 218: 567-588.

Claustre, H., P. Kerherve, J.-C. Marty, L. Prieur, C. Videau, and J.-H. Hecq. 1994. Phytoplankton dynamics associated with a geostrophic front: ecological and biogeochemical implications. Journal of Marine Research 52: 711-742.

Cloern, J.E. 2001. Our evolving conceptual model of the coastal eutrophication problem. Marine Ecology Progress Series 210: 223-253.

Comeau, L.A., A. Drapeau, T. Landry, and J. Davidson. 2008. Development of longline mussel farming and the influence of sleeve spacing in Prince Edward Island, Canada. Aquaculture 281: 56-62.

Conover, R.J. 1966. Assimilation of organic matter by zooplankton. Limnology and Oceanography 11: 338-345.

Costanza, R., R. d'Arge, R. de Groot, S. Farber, M. Grasso, B. Hannon, K. Limburg, S. Naeem, R.V. O’Neill, J. Paruelo, R.G. Raskin, P. Sutton, and M. van den Belt. 1997. The value of the world's ecosystems services and natural capital. Nature 387: 253-260.

Cranford, P.J., B.T. Hargrave, and L.I. Doucette. 2009. Benthic organic enrichment from suspended mussel (Mytilus edulis) culture in Prince Edward Island, Canada. Aquaculture 292: 189-196.

Cranford, P.J., P.M. Strain, M. Dowd, B.T. Hargrave, J. Grant, and M.-C. Archambault. 2007. Influence of mussel aquaculture on nitrogen dynamics in a nutrient enriched coastal embayment. Marine Ecology Progress Series 347: 61-78.

Cugier, P., A. Ménesguen, and J.-F. Guillaud. 2005. Three-dimensional (3D) ecological 
modelling of the Bay of Seine (English Channel, France). Journal of Sea Research 54: 104-124.

Dabrowski, T., K. Lyons, M. Curé, A. Berry, and G. Nolan. 2013. Numerical modelling of spatio-temporal variability of growth of Mytilus edulis (L.) and influence of its cultivation on ecosystem functioning. Journal of Sea Research 76: 5-21.

Danielescu, S., and K.T.B. MacQuarrie. 2011. Nitrogen loadings to two small estuaries, Prince Edward Island, Canada: a 2-year investigation of precipitation, surface water and groundwater contributions. Hydrological Processes 25: 945-957.

Deason, E.E. 1980. Grazing of Acartia hudsonica (A. clausi) on Skeletonema costatum in Narragansett Bay (USA): Influence of food concentration and temperature. Marine Biology 60: $101-113$.

DFO. 2006. An economic analysis of the mussel industry in Prince Edward Island. Moncton, New Brunswick, $25 \mathrm{p}$.

DiToro, D.M., P.R. Paquin, K. Subburamu, and D.A. Gruber. 1990. Sediment oxygen demand model: methane and ammonia oxidation. Journal of Environmental Engineering 116: 945986.

Dowd, M. 1997. On predicting the growth of cultured bivalves. Ecological Modelling 104: 113131.

Duarte, P., R. Meneses, A.J.S. Hawkins, M. Zhu, J. Fang, and J. Grant. 2003. Mathematical modelling to assess the carrying capacity for multi-species culture within coastal waters. Ecological Modelling 168: 109-143.

Dzierzbicka-Glowacka, L. 2005. A numerical investigation of phytoplankton and Pseudocalanus elongatus dynamics in the spring bloom time in the Gdansk Gulf. Journal of Marine Systems 53: 19-36.

Ehrhardt, M. 1983. Determination of particulate organic carbon and nitrogen. In Methods of seawater analysis, ed. K. Grasshoff, M. Ehrhardt and K. Kremling, 269-275. Weinheim, Germany: Verlag chemie.

FAO. 2012. The state of world fisheries and aquaculture 2012. Rome, 209 p.: Food and Agriculture Organization of the United Nations.

Feist, B.E., and C.A. Simenstad. 2000. Expansion rates and recruitment frequency of exotic smooth cordgrass, Spartina altemiflora (Loisel), colonizing unvegetated littoral flats in Willapa Bay, Washington. Estuaries 23: 267-274.

Ferreira, J.G., A.J.S. Hawkins, and S.B. Bricker. 2007. Management of productivity, environmental effects and profitability of shellfish aquaculture - the Farm Aquaculture Resource Management (FARM) model. Aquaculture 264: 160-174.

Ferreira, J.G., A.J.S. Hawkins, P. Monteiro, H. Moore, M. Service, P.L. Pascoe, L. Ramos, and A. Sequeira. 2008. Integrated assessment of ecosystem-scale carrying capacity in shellfish growing areas. Aquaculture 275: 138-151.

Filgueira, R., J. Grant, R. Stuart, and M.S. Brown. 2013. Ecosystem modelling for ecosystembased management of bivalve aquaculture sites in data-poor environments. Aquaculture Environment Interactions 4: 117-133.

Filgueira, R., T. Guyondet, L.A. Comeau, and J. Grant. 2014. A fully-spatial ecosystem-DEB model of oyster (Crassostrea virginica) carrying capacity in the Richibucto Estuary, Eastern Canada. Journal of Marine Systems. doi: 10.1016/j.jmarsys.2014.03.015.

Foreman, M.G. 1977. Manual for tidal heights analysis and previsions.Pacific Marine Science 
Report 77-10.

Gibbs, M.T. 2004. Interactions between bivalve shellfish farms and fishery resources. Aquaculture 240: 267-296.

Gifford, S., H. Dunstan, W.O. Connor, and G.R. Macfarlane. 2005. Quantification of in situ nutrient and heavy metal remediation by a small pearl oyster (Pinctada imbricata) farm at Port Stephens, Australia. Marine Pollution Bulletin 50: 417-422.

Giles, H., and C.A. Pilditch. 2006. Effects of mussel (Perna canaliculus) biodeposit decomposition on benthic respiration and nutrient fluxes. Marine Biology 150: 261-271.

Giusti, E., and S. Marsili-Libelli. 2006. An integrated model for the Orbetello lagoon ecosystem. Ecological Modelling 196: 379-394.

Goloway, F., and M. Bender. 1982. Diagenetic models of interstitial nitrate profiles in deep sea sediments. Limnology and Oceanography 27: 624-638.

Grangeré, K., A. Ménesguen, S. Lefebvre, C. Bacher, and S. Pouvreau. 2009. Modelling the influence of environmental factors on the physiological status of the Pacific oyster Crassostrea gigas in an estuarine embayment; The Baie des Veys (France). Journal of Sea Research 62: 147-158.

Grant, J., C. Bacher, P.J. Cranford, T. Guyondet, and M. Carreau. 2008. A spatially explicit ecosystem model of seston depletion in dense mussel culture. Journal of Marine Systems 73: $155-168$.

Grant, J., K.J. Curran, T.L. Guyondet, G. Tita, C. Bacher, V.G. Koutitonsky, and M. Dowd. 2007. A box model of carrying capacity for suspended mussel aquaculture in Lagune de la Grande-Entrée, Iles-de-la-Madeleine, Québec. Ecological Modelling 200: 193-206.

Grégoire, M., J.M. Beckers, J.C.J. Nihoul, and E. Stanev. 1998. Reconnaissance of the main Black Sea's ecohydrodynamics by means of a 3D interdisciplinary model. Journal of Marine Systems 16: 85-105.

Grégoire, M., and G. Lacroix. 2001. Study of the oxygen budget of the Black Sea waters using a 3D coupled hydrodynamical-biogeochemical model. Journal of Marine Systems 31: 175202.

Grégoire, M., C. Raick, and K. Soetaert. 2008. Numerical modeling of the central Black Sea ecosystem functioning during the eutrophication phase. Progress in Oceanography 76: 286-333.

Gren, I.-M., O. Lindahl, and M. Lindqvist. 2009. Values of mussel farming for combating eutrophication: an application to the Baltic Sea. Ecological Engineering 35: 935 - 945.

Griffin, S.L., M. Herzfeld, and D.P. Hamilton. 2001. Modelling the impact of zooplankton grazing on phytoplankton biomass during a dinoflagellate bloom in the Swan River Estuary, Western Australia. Ecological Engineering 16: 373-394.

Guyondet, T., S. Roy, V.G. Koutitonsky, J. Grant, and G. Tita. 2010. Integrating multiple spatial scales in the carrying capacity assessment of a coastal ecosystem for bivalve aquaculture. Journal of Sea Research 64: 341-359.

Haag, I. 2006. A basic water quality model for the River Neckar: Part 1 - model development, parameter sensitivity and identifiability, calibration and validation. Acta Hydrochimica et Hydrobiologica 34: 533-548.

Higgins, C.B., K. Stephenson, and B.L. Brown. 2011. Nutrient bioassimilation capacity of aquacultured oysters: quantification of an ecosystem service. Journal of Environmental Quality 40: 271-277. 
Hishamunda, N., N. Ridler, and E. Martone. 2014. Policy and governance in aquaculture: lessons learned and way forward. Fisheries and Aquaculture Technical Paper, Rome: FAO.

Hofman, P.A.G., S.A. de Jong, E.J. Wagenvoort, and A.J.J. Sandee. 1991. Apparent sediment diffusion coefficients for oxygen and oxygen consumption rates measured with microelectrodes and bell jars: applications to oxygen budgets in estuarine intertidal sediments (Oosterschelde, SW Netherlands). Marine Ecology Progress Series 69: 261-272.

Hummel, H., A.W. Fortuin, R.H. Bogaards, L. de Wolf, and A. Meyboom. 1989. Changes in Mytilus edulis in relation to short-term disturbances of the tide. In Proceedings 21st EMBS, ed. R.Z. Klekowski, L. Falkowski and E. Stycynska-Jurewicz, 77-89. Warsaw, Ossolineum.

Inglis, G.J., B.J. Hayden, and A.H. Ross. 2000. An overview of factors affecting the carrying capacity of coastal embayments for mussel culture. Christchurch, New Zealand: NIWA.

Jahnke, R.A., S.R. Emerson, and J.W. Murray. 1982. A model of oxygen reduction, denitrification and organic matter mineralization in marine sediments. Limnology and Oceanography 27: 610-623.

JGOFS. 1994. Primary Production by ${ }^{14} \mathrm{C}$. In Protocols for the Joint Global Ocean Flux Study (JGOFS) core measurements, ed. I.O. Commission, 128-135. Paris: UNESCO.

Ji, R., C. Davis, C. Chen, and R. Beardsley. 2008. Influence of local and external processes on the annual nitrogen cycle and primary productivity on Georges Bank: A 3-D biologicalphysical modeling study. Journal of Marine Systems 73: 31-47.

Jimenez-Montealegre, R., M.C.J. Verdegem, A. van Dam, and J.A.J. Verreth. 2002. Conceptualization and validation of a dynamic model for the simulation of nitrogen transformations and fluxes in fish ponds. Ecological Modelling 147: 123-152.

King, I.P. 1982. A finite element model for three dimensional flow. Vicksburg, Mississippi: report prepared by Resource Management Associates, Lafayette California, for U.S. Army Corps of Engineers, Waterways Experiment Station.

King, I.P. 2003. RMA-11 - A three dimensional finite element model for water quality in estuaries and streams. Resource Modelling Associates, Sydney, Australia. 84p.

Kooijman, S.A.L.M. 2000. Dynamic energy and mass budgets in biological systems. Cambridge: Cambridge University Press.

Koutitonsky, V.G., T. Guyondet, A. St-Hillaire, S.C. Courtenay, and A.D. Bohgen. 2004. Water renewal estimates for aquaculture developments in the Richibucto Estuary, Canada. Estuaries 27: 839-850.

Larsen, P., and G. Ashton. 1986. Thermal regime of lakes and rivers. In River and lake ice engineering, ed. G. Ashton, 203-260. Highlands Ranch, Colorado: Water Resources Publications.

Lehane, C., and J. Davenport. 2006. A 15-month study of zooplankton ingestion by farmed mussels (Mytilus edulis) in Bantry Bay, Southwest Ireland. Estuarine, Coastal and Shelf Science 67: 645-652.

Li, M., A. Gargett, and K.L. Denman. 2000. What determines seasonal and interannual variability of phytoplankton and zooplankton in strongly estuarine systems? Application to the semi-enclosed estuary of Strait of Georgia and Juan de Fuca Strait. Estuarine, Coastal and Shelf Science 50: 467-488.

Li, Y.-H., and S. Gregory. 1974. Diffusion of ions in sea water and in deep-sea sediments. Geochimica et Cosmochimica Acta 38: 703-714. 
Lindahl, O., R. Hart, B. Hernroth, S. Kollberg, L. Loo, L. Olrog, and A. Rehnstam-Holm. 2005. Improving marine water quality by mussel farming: a profitable solution for Swedish Society. Ambio 34: 131-138.

Liss, P.S., and L. Merlivat. 1986. Air-Sea gas exchange rates: Introduction and synthesis. In The Role of Air-Sea Exchange in Geochemical Cycling, ed. P. Buat-Menard. Reidel, Hingham, MA, p. 113-127.

Lohrenz, S.E., G.L. Fahnenstiel, D.G. Redalje, G.A. Lang, M.J. Dagg, T.E. Whitledge, and Q. Dortch. 1999. Nutrients, irradiance, and mixing as factors regulating primary production in coastal waters impacted by the Mississippi River plume. Continental Shelf Research 19: 1113-1141.

Lutz, R.A., K. Chalermwat, A.J. Figueras, R.G. Gustafson, and C.R. Newell. 1991. Mussel aquaculture in marine and estuarine environments throughout the world. In Estuarine and marine bivalve mollusk culture, ed. W. Menzel. CRC Press. Boca Raton, p. 57-98.

Maa, J.P.-Y., L. Sanford, and J.P. Halka. 1998. Sediment resuspension characteristics in Baltimore Harbor, Maryland. Marine Geology 146: 137-145.

Maar, M., T.G. Nielsen, and J.K. Petersen. 2008. Depletion of plankton in a raft culture of Mytilus galloprovincialis in Ria de Vigo, NW Spain. II. Zooplankton. Aquatic Biology 4: 127-141.

Mallet, A.L., C.E.A. Carver, and K.R. Freeman. 1990. Summer mortality of the blue mussel in eastern Canada: spatial, temporal, stock and age variation. Marine Ecology Progress Series 67: 35-41.

Marinov, D., L. Galbiati, G. Giordani, P. Viaroli, A. Norro, S. Bencivelli, and J.M. Zaldívar. 2007. An integrated modelling approach for the management of clam farming in coastal lagoons. Aquaculture 269: 306-320.

McKindsey, C.W., P. Archambault, M.D. Callier, and F. Olivier. 2011. Influence of suspended and off-bottom mussel culture on the sea bottom and benthic habitats: a review. Canadian Journal of Zoology 89: 622-646.

McKindsey, C.W., H. Thetmeyer, T. Landry, and W. Silvert. 2006. Review of recent carrying capacity models for bivalve culture and recommendations for research and management. Aquaculture 261: 451-462.

McLeod, K., and H. Leslie. 2009. Ecosystem-based management for the oceans. Washington, DC: IslandPress.

Meeuwig, J.J. 1999. Predicting coastal eutrophication from land-use: an empirical approach to small non-stratified estuaries. Marine Ecology Progress Series 176: 231-241.

Mistri, M., and C. Munari. 2012. Clam farming generates CO2: A study case in the Marinetta lagoon (Italy). Marine Pollution Bulletin 64: 2261-2264.

Myrand, B., H. Guderley, and J.H. Himmelman. 2000. Reproduction and summer mortality of blue mussels Mytilus edulis in the Magdalen Islands, southern Gulf of St. Lawrence. Marine Ecology Progress Series 197: 193-207.

Newell, C.R., H. Hidu, B.J. McAlice, G. Podniesinski, F. Short, and L. Kindblom. 1991. Recruitment and commercial seed procurement of the blue mussel Mytilus edulis in Maine. Journal of the World Aquaculture Society 22: 134-152.

Newell, R.I.E. 2004. Ecosystem influences of natural and cultivated populations of suspensionfeeding bivalve molluscs: a review. Journal of Shellfish Research 23: 51-61.

Nixon, S.W. 1995. Coastal marine eutrophication: a definition, social causes, and future 
concerns. Ophelia 41: 199-219.

Nobre, A.M., J.G. Ferreira, J.P. Nunes, X. Yan, S. Bricker, R. Corner, S. Groom, H. Gu, A.J.S. Hawkins, R. Hutson, D. Lan, J.D. Lencart e Silva, P. Pascoe, T. Telfer, X. Zhang, and M. Zhu. 2010. Assessment of coastal management options by means of multilayered ecosystem models. Estuarine, Coastal and Shelf Science 87: 43-62.

Nunes, J.P., J.G. Ferreira, S.B. Bricker, B. O'Loan, T. Dabrowski, B. Dallaghan, A.J.S. Hawkins, B. O'Connor, and T. O'Carroll. 2011. Towards an ecosystem approach to aquaculture: Assessment of sustainable shellfish cultivation at different scales of space, time and complexity. Aquaculture 315: 369-383.

Nunes, J.P., J.G. Ferreira, F. Gazeau, J. Lencart-Silva, X.L. Zhang, M.Y. Zhu, and J.G. Fang. 2003. A model for sustainable management of shellfish polyculture in coastal bays. Aquaculture 219: 257-277.

Oguz, T., H.W. Ducklow, P. Malanotte-Rizzoli, J.W. Murray, E.A. Shushkina, V.I. Vedernikov, and U. Unluata. 1999. A physical-biochemical model of plankton productivity and nitrogen cycling in the Black Sea. Deep-Sea Research I 46: 597-636.

Okunishi, T., M.J. Kishi, A. Shiomoto, H. Tanaka, and T. Yamashita. 2005. An ecosystem modeling study of spatio-temporal variations of phytoplankton distribution in the Okhotsk Sea. Continental Shelf Research 25: 1605-1628.

Parker, R.A. 1993. Dynamic models for ammonium inhibition of nitrate uptake by phytoplankton. Ecological Modelling 66: 113-120.

Petersen, J.K., B. Hasler, K. Timmermann, P. Nielsen, D.B. Tørring, M.M. Larsen, and M. Holmer. 2014. Mussels as a tool for mitigation of nutrients in the marine environment. Marine Pollution Bulletin. doi: 10.1016/j.marpolbul.2014.03.006.

Petersen, J.K., T.G. Nielsen, L. van Duren, and M. Maar. 2008. Depletion of plankton in a raft culture of Mytilus galloprovincialis in Ria de Vigo, NW Spain. I. Phytoplankton. Aquatic Biology 4: 113-125.

Peterson, B.J., and K.L. Heck Jr. 1999. The potential for suspension feeding bivalves to increase seagrass productivity. Journal of Experimental Marine Biology and Ecology 240: 37-52.

Pett, R.J. 1989. Kinetics of microbial mineralization of organic carbon from detrital Skelatonema costatum cells. Marine Ecology Progress Series 52: 123-128.

Phelps, H.L. 1994. The Asiatic Clam (Corbicula fluminea) Invasion and System-Level Ecological Change in the Potomac River Estuary Near Washington, D.C. Estuaries 17: 614-621.

Pinazo, C., P. Marsaleix, B. Millet, C. Estournel, and R. Véhil. 1996. Spatial and temporal variability of phytoplankton biomass in upwelling areas of the northwestern Mediterranean: a coupled physical and biogeochemical modelling approach. Journal of Marine Systems 7: 161-191.

Plew, D.R. 2011. Shellfish farm-induced changes to tidal circulation in an embayment, and implications for seston depletion. Aquaculture Environment Interactions 1: 201-214.

Pouvreau, S., Y. Bourles, S. Lefebvre, A. Gangnery, and M. Alunno-Bruscia. 2006. Application of a dynamic energy budget model to the Pacific oyster, Crassostrea gigas, reared under various environmental conditions. Journal of Sea Research 56: 156-167.

Radach, G., and A. Moll. 2006. Review of three-dimensional ecological modelling related to the North Sea shelf system. Part II: model validation and data needs. Oceanography and Marine Biology: An Annual Review 44: 1-60. 
Ranasinghe, R., and C. Pattiaratchi. 1998. Flushing characteristics of a seasonally-open tidal inlet: A numerical study. Journal of Coastal Research 14: 1405-1421.

Raymond, B.G., C.S. Crane, and D.K. Cairns. 2002. Nutrient and chlorophyll trends in Prince Edward Island estuaries. In Effects of land use practices on fish, shellfish, and their habitats on Prince Edward Island, ed. D.K. Cairns, 142-153. Ottawa, Canada: Canadian Technical Report of Fisheries and Aquatic Sciences. No. 2408.

Redfield, A.C. 1934. On the proportions of organic derivatives in sea water and their relation to the composition of plankton. In James Johnstone Memorial Volume, pp. 176-192. Liverpool University Press.

Rice, J., V. Trujill, S. Jennings, K. Hylland, O. Hagstrom, A. Astudillo, and J.N. Jensen. 2005. Guidance on the application of the ecosystem approach to management of human activities in the European marine environment. In ICES Cooperative Research Report Copenhagen: International Council for the Exploration of the Sea.

Robson, B.J., and D.P. Hamilton. 2004. Three-dimensional modelling of a Microcystis bloom event in the Swan River estuary, Western Australia. Ecological Modelling 174: 203-222.

Romero, J.R., J.P. Antenucci, and J. Imberger. 2004. One- and three-dimensional biogeochemical simulations of two differing reservoirs. Ecological Modelling 174: 143160.

Rosenberg, R. 1985. Eutrophication-the future marine coastal nuisance? Marine Pollution Bulletin 16: 227-231.

Rosland, R., C. Bacher, Ø. Strand, J. Aure, and T. Strohmeier. 2011. Modelling growth variability in longline mussel farms as a function of stocking density and farm design. Journal of Sea Research 66 318-330.

Rosland, R., Ø. Strand, M. Alunno-Bruscia, C. Bacher, and T. Strohmeier. 2009. Applying Dynamic Energy Budget (DEB) theory to simulate growth and bio-energetics of blue mussels under low seston conditions. Journal of Sea Research 62: 49-61.

Ruardij, P., and W. van Raaphorst. 1995. Benthic nutrient regeneration in the ERSEM ecosystem model of the North Sea. Netherlands Journal of Sea Research 33: 453-483.

Savenkoff, C., A.F. Vézina, S. Roy, B. Klein, C. Lovejoy, J.C. Therriault, L. Legendre, R. Rivkin, C. Bérubé, J.E. Tremblay, and N. Silverberg. 2000. Export of biogenic carbon and structure and dynamics of the pelagic food web in the Gulf of St. Lawrence Part 1.

Seasonal variations. Deep Sea Research Part II: Topical Studies in Oceanography 47: 585607.

Scavia, D., J.C. Field, D.F. Boesch, R.W. Buddemeier, V. Burkett, D.R. Cayan, M. Fogarty, M.A. Harwell, R.W. Howarth, C. Mason, D.J. Reed, T.C. Royer, A.H. Sallenger, and J.G. Titus. 2002. Climate change impacts on U.S. coastal and marine ecosystems. Estuaries 25: 149-164.

Schulte, E.H. 1975. Influence of algal concentration and temperature on the filtration rate of Mytilus edulis. Marine Biology 30: 331-341.

Smaal, A.C. 2002. European mussel cultivation along the Atlantic coast: production status, problems and perspectives. Hydrobiologia 484: 89-98.

Smith, G., and A. Ramsay. 2012. PEI mussel monitoring program. Montague, PEI: PEI Department of Fisheries, Aquaculture and Rural Development.

Smith, V.H. 2006. Responses of estuarine and coastal marine phytoplankton to nitrogen and phosphorus enrichment. Limnology and Oceanography 51: 377-384. 
Soto, D., J. Aguilar-Manjarrez, and N. Hishamunda. 2008. Building an ecosystem approach to aquaculture. In FAO/Universitat de les Illes Balears Expert Workshop. 7-11 May 2007, Palma de Mallorca, Spain, ed. FAO. Palma de Mallorca, Spain: FAO Fisheries and Aquaculture Proceedings. No. 14.

StatisticsCanada. 2011. Aquaculture statistics 2010. Agriculture Division, Livestock Section. Catalogue no. 23-222-X. Ottawa.

Steele, J.H. 1962. Environmental control of photosynthesis in the sea. Limnology and Oceanography 7: 137- 150.

Strickland, J.D.H., and T.R. Parsons. 1972. A practical handbook of seawater analysis. Bulletin 167: Fisheries research board of Canada.

Strohmeier, T., A. Duinker, Ø. Strand, and J. Aure. 2008. Temporal and spatial variation in food availability and meat ratio in a longline mussel farm (Mytilus edulis). Aquaculture 276: 83-90.

Taboada, F.G., and R. Anadón. 2012. Patterns of change in sea surface temperature in the North Atlantic during the last three decades: beyond mean trends. Climatic Change 115: 419-431.

Theede, H. 1963. Experimentelle Untersuchungen uber die Filtrationsleistung der Miesmuschel Mytilus edulis. Kieler Meeresforschung 19: 20-41.

Tian, R.C., A.F. Vézina, L. Legendre, R.G. Ingram, B. Klein, T. Packard, S. Roy, C. Savenkoff, N. Silverberg, J.-C. Therriault, and J.-É. Tremblay. 2000. Effects of pelagic food-web interactions and nutrient remineralization on the biogeochemical cycling of carbon: a modeling approach. Deep-Sea Research II 47: 637-662.

Troost, K., E. Gelderman, P. Kamermans, A.C. Smaal, and W.J. Wolff. 2009. Effects of an increasing filter feeder stock on larval abundance in the Oosterschelde estuary (SW Netherlands). Journal of Sea Research 61: 153-164.

Trottet, A., S. Roy, E. Tamigneaux, and C. Lovejoy. 2007. Importance of heterotrophic planktonic communities in a mussel culture environment: the Grande-Entrée Lagoon, Magdalen Islands (Québec, Canada). Marine Biology 151: 377-392.

Twilley, R.R., W.M. Kemp, K.W. Staver, J.C. Stevenson, and W.R. Boynton. 1985. Nutrient enrichment of estuarine submersed vascular plant communities. 1. Algal growth and effects on production of plants and associated communities. Marine Ecology Progress Series 23: 179-191.

Valiela, I., J. McClelland, J. Hauxwell, P.J. Behr, D. Hersh, and K. Foreman. 1997. Macroalgal blooms in shallow estuaries: Controls and ecophysiological and ecosystem consequences. Limnology and Oceanography 42: 1105-1118.

van der Veer, H.W., J.F.M.F. Cardoso, and J. van der Meer. 2006. The estimation of DEB parameters for various Northeast Atlantic bivalve species. Journal of Sea Research 56: 107-124.

Vasseur, L., and N.R. Catto. 2008. Canada Atlantique. In Vivre avec les changements climatiques au Canada: édition 2007, ed. D.S. Lemmen, F.J. Warren, J. Lacroix and E. Bush, 119-170. Ottawa: Gouvernement du Canada.

Villars, M., I. de Vries, M. Bokhorst, J. Ferreira, S. Gellers-Barkman, B. Kelly-Gerreyn, C. Lancelot, A. Menesguen, A. Moll, J. Pätsch, G. Radach, M. Skogen, H. Soiland, E. Svendsen, and H.J. Vested. 1998. Report of the ASMO modelling workshop on eutrophication Issues, 5-8 November 1996, ed. OSPAR Commission. Report 102. RIKZ, The Hague, The Netherlands. 
Wainright, S.C., and C.S. Hopkinson Jr. 1997. Effects of sediment resuspension on organic matter processing in coastal environments: a simulation model. Journal of Marine Systems 11: 353-368.

Walker, T.R., and J. Grant. 2009. Quantifying erosion rates and stability of bottom sediments at mussel aquaculture sites in Prince Edward Island, Canada. Journal of Marine Systems 75: 46-55.

Wall, C.C., B.J. Peterson, and C.J. Gobler. 2011. The growth of estuarine resources (Zostera marina, Mercenaria mercenaria, Crassostrea virginica, Argopecten irradians, Cyprinodon variegatus) in response to nutrient loading and enhanced suspension feeding by adult shellfish. Estuaries and Coasts 34: 1262-1277.

Walters, R.A., and C. Heston. 1982. Removing tidal period variations from time-series data using low-pass digital filters. Journal of Physical Oceanography 12: 112-115.

Wheat, E., and J.L. Ruesink. 2013. Commercially-cultured oysters (Crassostrea gigas) exert topdown control on intertidal pelagic resources in Willapa Bay, Washington, USA. Journal of Sea Research 81: 33-39.

Widdows, J., P. Fieth, and C.M. Worrall. 1979. Relationships between seston, available food and feeding activity in the common mussel Mytilus edulis. Marine Biology 50: 195-207.

Zhang, J., P.K. Hansen, J. Fang, W. Wang, and Z. Jiang. 2009. Assessment of the local environmental impact of intensive marine shellfish and seaweed farming-Application of the MOM system in the Sungo Bay, China. Aquaculture 287: 304-310. 
Table 1: Sampling and analysis methods used for bio-chemical parameter determination.

\begin{tabular}{|c|c|c|c|}
\hline Parameter & Sampling method & Analysis method & Results - Units \\
\hline SPM-POM & $\begin{array}{l}\text { Water filtration. Filtered volume }=600-1200 \mathrm{~mL} \\
\text { Whatman GF-F } \varnothing 47 \mathrm{~mm}) \text { pre-ashed }\left(500^{\circ} \mathrm{C}, 5 \mathrm{~h}\right) \text {, } \\
\text { pre-weighed filters. } \\
\text { Conservation: }-40^{\circ} \mathrm{C} .\end{array}$ & $\begin{array}{l}\text { Difference of filter mass before and } \\
\text { after filtration and drying for } 24 \mathrm{~h} \text { at } \\
70^{\circ} \mathrm{C} \text { (SPM) and after combustion at } \\
500^{\circ} \mathrm{C} \text { for } 5 \mathrm{~h} \text { (POM). } \\
\text { (Aminot, 1983). }\end{array}$ & $\begin{array}{l}\text { Suspended Particulate Matter and Particulate } \\
\text { Organic Matter concentrations } \\
\left(\mu \mathrm{g} \mathrm{L}^{-1}\right)\end{array}$ \\
\hline $\begin{array}{l}\text { POM } \\
\text { composition }\end{array}$ & $\begin{array}{l}\text { Water filtration. Filtered volume }=100 \mathrm{~mL} \\
\text { Whatman GF-F }(\varnothing 25 \mathrm{~mm}) \text { pre-ashed filters }(500 \\
\left.{ }^{\circ} \mathrm{C} \text { for } 5 \mathrm{~h}\right) . \\
\text { Conservation: }-80{ }^{\circ} \mathrm{C} .\end{array}$ & $\begin{array}{l}\text { CHN analysis. } \\
\text { Method described by Ehrhardt (1983). } \\
\text { Combustion at } 925^{\circ} \mathrm{C} \text {, with } \mathrm{O}_{2} \text {. }\end{array}$ & $\begin{array}{l}\text { Particulate organic Carbon and Nitrogen } \\
\text { concentrations } \\
\left(\mu \mathrm{g} \mathrm{L}^{-1}\right)\end{array}$ \\
\hline Phytoplankton & $\begin{array}{l}\text { Water filtration. Filtered volume }=100 \mathrm{~mL} \\
\text { Whatman GF-F }(\varnothing 25 \mathrm{~mm}) \\
\text { Conservation: }-40^{\circ} \mathrm{C} .\end{array}$ & $\begin{array}{l}\text { Trilogy Fluorometer, Turner Designs. } \\
\text { Fluorometric analysis after acetone } \\
\text { (90\%) extraction } \\
\text { (Strickland \& Parsons 1972) }\end{array}$ & $\begin{array}{l}\text { Chlorophyll } a \text { concentration } \\
\left(\mu \mathrm{g} \mathrm{L}^{-1}\right)\end{array}$ \\
\hline Nutrients & $\begin{array}{l}\text { Pre-filtered water sample (syringe filter, } 0.8 \mu \mathrm{m} \text { ) } \\
\text { Conservation: } 4.5 \mathrm{~mL} \text { in } \mathrm{HCl} \text { washed vials, }-80^{\circ} \mathrm{C} \text {. }\end{array}$ & $\begin{array}{l}\text { Seal Automatic Analyser III } \\
\text { Methods described by Strickland \& } \\
\text { Parsons (1972). }\end{array}$ & $\begin{array}{l}\text { Nitrite-nitrate, phosphate and silicate } \\
\text { concentrations } \\
(\mu \mathrm{M})\end{array}$ \\
\hline
\end{tabular}


Table 2: Summary of model climatic scenario characteristics expressed as departures from the 20112012 baseline. nc: no change.

\begin{tabular}{ccccccccc}
\hline & $\begin{array}{c}\text { River } \\
\text { discharge }\end{array}$ & $\begin{array}{c}\text { River } \\
\text { Nitrate }\end{array}$ & Temperature & \multicolumn{5}{c}{ Wir } \\
\cline { 3 - 8 } & & & & $\begin{array}{c}\text { Annual } \\
\text { mean }\end{array}$ & $\begin{array}{c}\text { Seasonal } \\
\text { maxima }\end{array}$ & $\begin{array}{c}\text { Seasonal } \\
\text { minima }\end{array}$ & $\begin{array}{c}\text { Timing of Timing of } \\
\text { maxima } \\
\text { minima }\end{array}$ \\
\hline Scenario 1980 & $\mathrm{nc}$ & $-50 \%$ & $\mathrm{nc}$ & $-0.9^{\circ} \mathrm{C}$ & $-1.5^{\circ} \mathrm{C}$ & $-0.3{ }^{\circ} \mathrm{C}$ & $\mathrm{nc}$ & $+20 \mathrm{~d}$ \\
Scenario 2050 & $+10 \%$ & $\mathrm{nc}$ & $+4{ }^{\circ} \mathrm{C}$ & $\begin{array}{c}+2.0 \\
{ }^{\circ} \mathrm{C}\end{array}$ & $+3.5^{\circ} \mathrm{C}$ & $+0.4{ }^{\circ} \mathrm{C}$ & $\mathrm{nc}$ & $-28 \mathrm{~d}$ \\
\hline
\end{tabular}


Table 3: Harmonic analysis of observed and predicted water level time series with $95 \%$ confidence intervals for the four main tidal constituents (O1, K1, M2 and S2) and fraction of the total variance of observed level fluctuations explained by the model at all sampled stations inside the domain.

\begin{tabular}{|c|c|c|c|c|c|c|c|c|c|c|c|}
\hline & \multicolumn{2}{|c|}{ Amplitude (m) } & \multicolumn{2}{|l|}{ Phase $\left(^{\circ}\right)$} & & \multicolumn{2}{|c|}{ Amplitude (m) } & \multicolumn{2}{|l|}{ Phase $\left(^{\circ}\right)$} & & \multirow{2}{*}{$\begin{array}{c}\text { Variance } \\
\text { explained (\%) }\end{array}$} \\
\hline & Observed & Predicted & Observed & Predicted & & Observed & Predicted & Observed & Predicted & & \\
\hline & O1 & & & & & K1 & & & & & \\
\hline SP0 & $0.13 \pm 0.01$ & $0.13 \pm 0.01$ & $274.9 \pm 6.9$ & $277.5 \pm 6.2$ & SP0 & $0.13 \pm 0.01$ & $0.13 \pm 0.01$ & $298.6 \pm 6.4$ & $301.9 \pm 5.4$ & SP0 & 86.2 \\
\hline $\mathrm{SP} 2 \mathrm{~b}$ & $0.14 \pm 0.01$ & $0.13 \pm 0.01$ & $282.6 \pm 5.8$ & $283.1 \pm 5.7$ & $\mathrm{SP} 2 \mathrm{~b}$ & $0.13 \pm 0.02$ & $0.13 \pm 0.01$ & $307.3 \pm 5.4$ & $308.6 \pm 5.6$ & $\mathrm{SP} 2 \mathrm{~b}$ & 94.3 \\
\hline SP4 & $0.13 \pm 0.01$ & $0.13 \pm 0.01$ & $283.2 \pm 5.8$ & $283.7 \pm 6.2$ & SP4 & $0.13 \pm 0.02$ & $0.13 \pm 0.01$ & $307.7 \pm 6.2$ & $309.9 \pm 5.8$ & SP4 & 88.3 \\
\hline & M2 & & & & & S2 & & & & & \\
\hline SP0 & $0.09 \pm 0.00$ & $0.09 \pm 0.01$ & $237.3 \pm 2.4$ & $242.3 \pm 4.6$ & SP0 & $0.02 \pm 0.00$ & $0.02 \pm 0.01$ & $319.4 \pm 11.4$ & $345.5 \pm 17.4$ & & \\
\hline $\mathrm{SP} 2 \mathrm{~b}$ & $0.09 \pm 0.00$ & $0.09 \pm 0.01$ & $254.2 \pm 2.8$ & $252.9 \pm 5.1$ & $\mathrm{SP} 2 \mathrm{~b}$ & $0.02 \pm 0.00$ & $0.02 \pm 0.01$ & $356.2 \pm 12.5$ & $362.1 \pm 17.8$ & & \\
\hline SP4 & $0.09 \pm 0.01$ & $0.09 \pm 0.01$ & $255.2 \pm 3.1$ & $253.9 \pm 5.8$ & SP4 & $0.02 \pm 0.01$ & $0.02 \pm 0.01$ & $358.2 \pm 12.3$ & $365.5 \pm 21.0$ & & \\
\hline
\end{tabular}


Table 4: Cost function. Measure of model fit for all stations and variables with available observations (T: water temperature, NO3: nitrate, P: phytoplankton, D: organic detritus, L: mussel shell length and DW: mussel meat dry weight). $(\mathrm{Cx}<1,1 \leq \mathrm{Cx}<2,2 \leq \mathrm{Cx}<3$ and $\mathrm{Cx}>3$ correspond to model results respectively very good, good, reasonable and poor). ND: no observation data available for comparison.

\begin{tabular}{ccccccc} 
& T & NO3 & P & D & L & DW \\
\hline SP1 & 0.19 & 0.21 & 2.07 & 0.72 & ND & ND \\
SP2 & 0.17 & 0.12 & 1.46 & 1.09 & 0.12 & 0.23 \\
SP3 & 0.25 & 0.10 & 1.45 & 1.22 & ND & ND \\
SP4 & 0.27 & 0.06 & 1.54 & 1.06 & ND & ND \\
\hline
\end{tabular}


Table 5: Intensity of bivalve aquaculture at system-scale in important production areas around the world.

\begin{tabular}{|c|c|c|c|c|}
\hline Site & $\begin{array}{l}\text { Total } \\
\text { Area } \\
(\mathrm{km} 2) \\
\end{array}$ & $\begin{array}{c}\text { Bivalve } \\
\text { culture } \\
\text { Coverage }(\%) \\
\end{array}$ & Species & Reference \\
\hline St Peter's Bay (Canada) & 15.8 & 39.6 & Mytilus edulis & This study \\
\hline Tracadie Bay (Canada) & 19.3 & 40.0 & Mytilus edulis & Comeau et al. 2008 \\
\hline Xiangshan Gang (China) & 365.0 & 8.5 & $\begin{array}{l}\text { Ostrea plicatula, Sinonvacula constricta } \\
\text { Ruditapes philippinarum, Tegillarca granosa }\end{array}$ & Nobre et al. 2010 \\
\hline Sungo Bay (China) & 144.0 & 32.1 & Crassostrea gigas, Chlamys farreri & Zhang et al. 2009 \\
\hline Thau Lagoon (France) & 70.0 & 20.0 & Crassostrea gigas, Mytilus galloprovincialis & Bacher et al. 1997, Chapelle 1995 \\
\hline Marinetta Lagoon (Italy) & 11.5 & 9.1 & Ruditapes philippinarum & Mistri and Munari 2012 \\
\hline Sacca di Goro (Italy) & 26.0 & 34.1 & Ruditapes philippinarum & Marinov 2007 \\
\hline Oosterschelde Estuary (Netherlands) & 351.0 & 5.8 & Crassostrea gigas, Mytilus edulis & Smaal 2002, Troost et al. 2009 \\
\hline Beatrix Bay (New Zealand) & 24.0 & 8.4 & Perna canaliculus & Christensen et al. 2003 \\
\hline Port Ligar (New Zealand) & 8.3 & 10.6 & Perna canaliculus & Plew 2011 \\
\hline Waihinau Bay (New Zealand) & 2.2 & 9.5 & Perna canaliculus & Plew 2011 \\
\hline Ria de Arousa (Spain) & 240.0 & 10.0 & Mytilus galloprovincialis & Alvarez-Salgado et al. 1996, Lutz et al. 1991 \\
\hline Willapa Bay (USA) & 347.0 & 10.0 & Crassostrea gigas, Ruditapes philippinarum & Banas 2005, Feist and Simenstad 2000, Wheat and Ruesink 2013 \\
\hline
\end{tabular}




\section{FIGURE CAPTIONS}

Fig. 1 Bathymetric map and location of St Peter's Bay (SPB) showing mussel farms (white polygons) and sampling stations. The meteorological station (M) is marked with a star

Fig. 2 Annual time series of water temperature at station SPext as observed in 2011 and projections based on the respective climate scenarios for 1980 and 2050 (see text for details)

Fig. 3 Hydrodynamic model calibration. Comparison of observed and predicted time series of water level fluctuations at stations SP0, SP2b and SP4 and currents along their principal axis at station SP0

Fig. 4 Biogeochemical model and Dynamic Energy Budget (DEB) calibration. Comparison of observed and predicted time series of the main variables (a: water temperature, b: nitrate-NO3, c: phytoplankton-P, d: organic detritus-D, e: mussel shell length-L and f: mussel meat dry weightDW) over the 2011-2012 annual cycle at station SP2. Winter temperatures were only recorded in 2010-2011; they are reported here for a more complete comparison. The shaded area on the phytoplankton graph shows the timing of the spring bloom just outside SPB as observed in remote sensing data (4 km MODIS-Aqua, Giovanni online data system, NASA GESDISC, http://disc.sci.gsfc.nasa.gov/giovanni)

Fig. 5 Spatial distribution of the renewal time of SPB waters by water from the Gulf of Saint Lawrence and the rivers

Fig. 6 Spatial distribution of the relative change in the different model variables (ammonium: NH4, phytoplankton: P, organic detritus: D and zooplankton: Z) induced by the introduction of mussel culture activity at present day stock levels. Negative values indicate a decrease in the annual mean concentration when cultured mussels are introduced

Fig. 7 Spatial distribution of the relative change in net phytoplankton primary production (top panel) and sedimentation rates (bottom panel) induced by the introduction of mussel culture activity at present day stock levels. Negative values indicate a decrease in the annual mean rate when cultured mussels are introduced

Fig. 8 Effects of increasing mussel stock (expressed as density in the farmed areas) on the spatially-averaged annual mean concentration of the model variables (a: dissolved inorganic nitrogen-DIN, b: phytoplankton-P, c: organic detritus-D and $\mathrm{d}$ : zooplankton-Z in SPB for the three different climatic scenarios). Effects on the summer mean (June-August) are also presented for $\mathrm{P}$ in 2011

Fig. 9 Annual cycles of spatially-averaged concentrations of P and DIN in SPB for the 2011 conditions and for the different mussel stocks tested (NoM: no mussel aquaculture, $\mathrm{n}_{\mathrm{M}} / 4, \mathrm{n}_{\mathrm{M}} / 2$, $n_{M}$ and $n_{M} \times 2$, with present day stocks corresponding to a mussel density of $n_{M}=94$ ind m in the farmed areas) 
Fig. 10 Effects of increasing mussel stocks (expressed as density in the farmed areas) on the spatially-averaged annual mean of different process rates (a: P net primary production, b: grazing of $\mathrm{P}$ by $\mathrm{Z}$ and mussels, c: DIN uptake by $\mathrm{P}$ and $\mathrm{d}$ : pelagic organic matter remineralization and excretion by $Z$ and mussels) in SPB for the three different climatic scenarios 


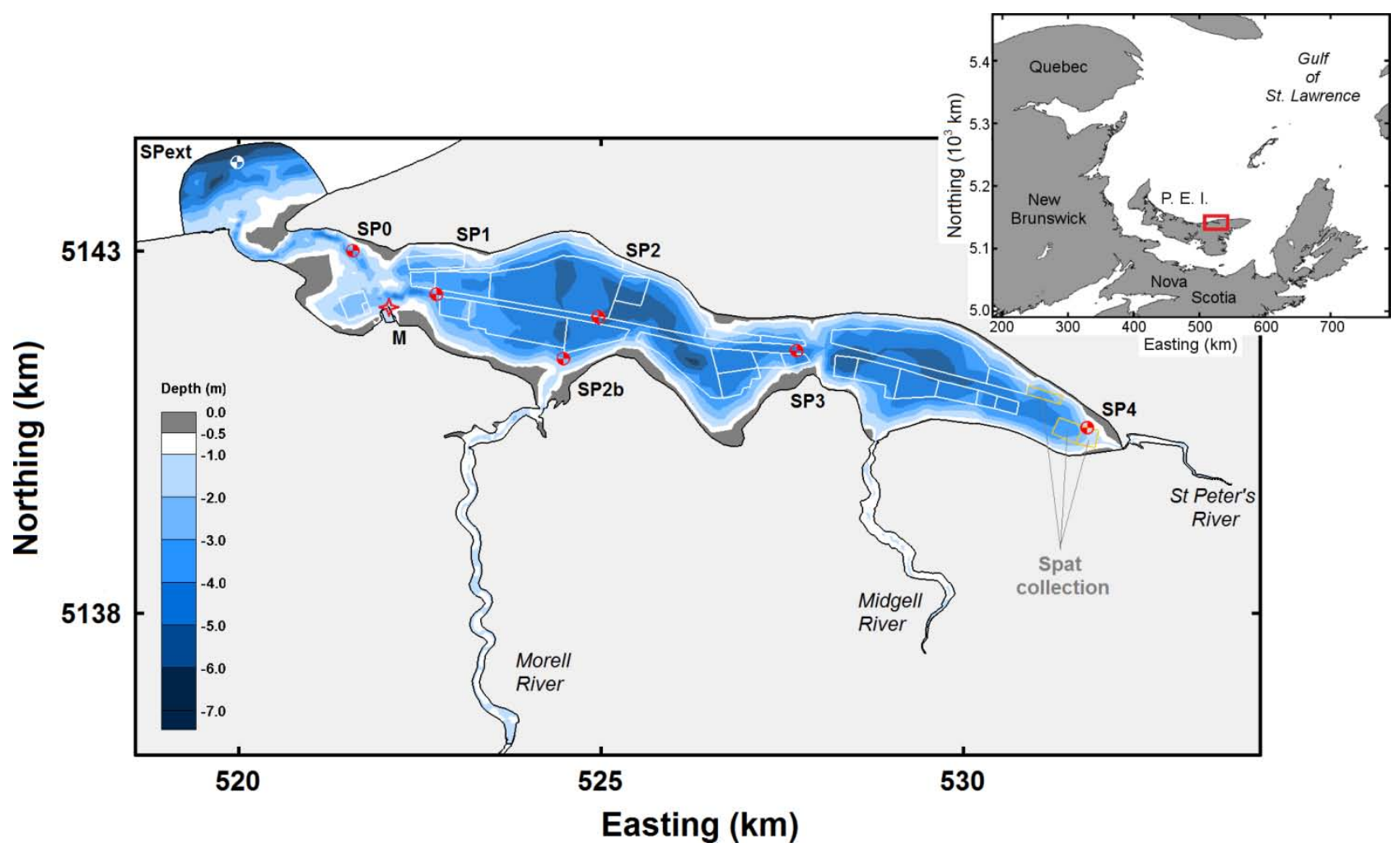

Figure 1

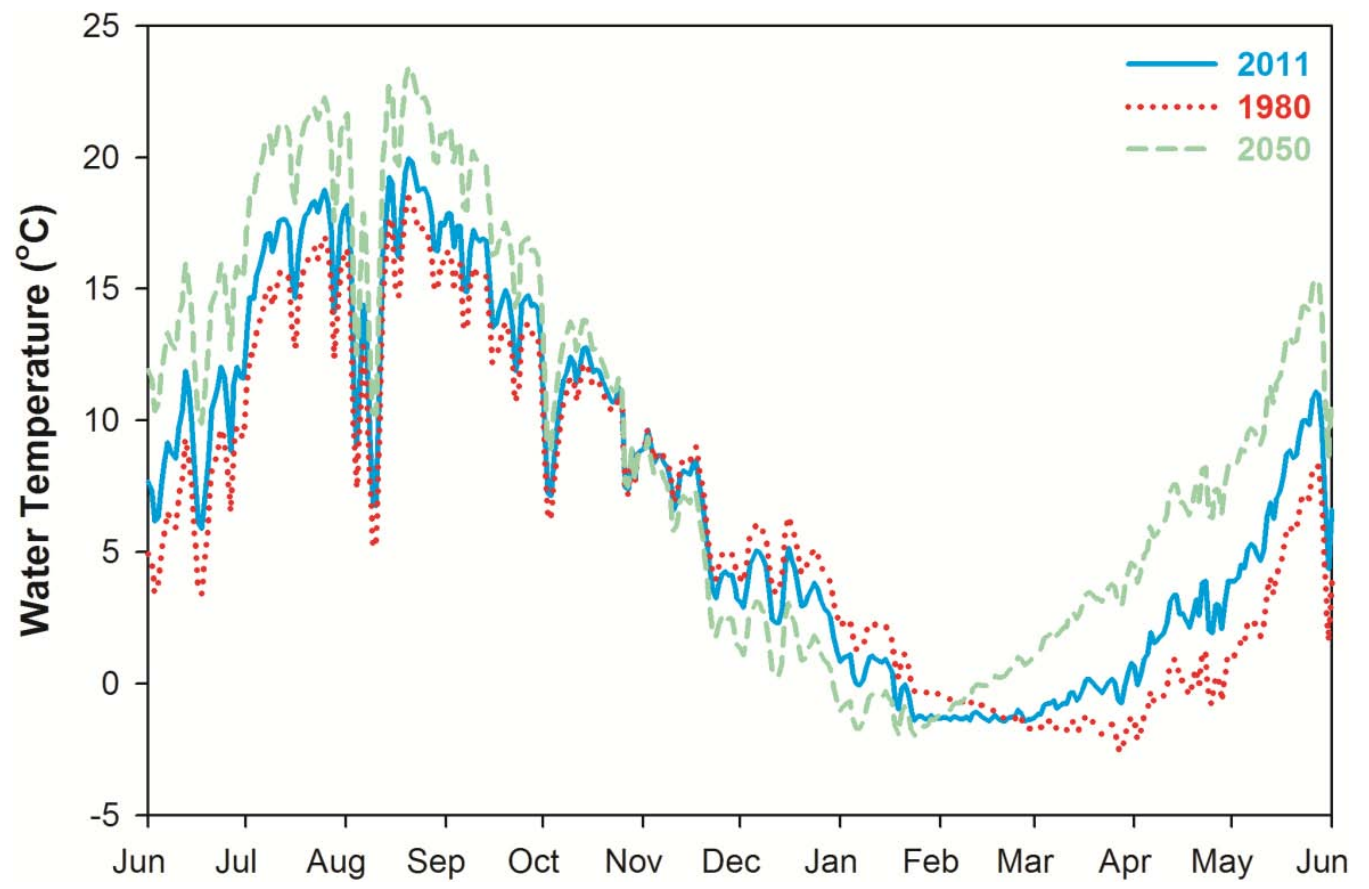

Figure 2 

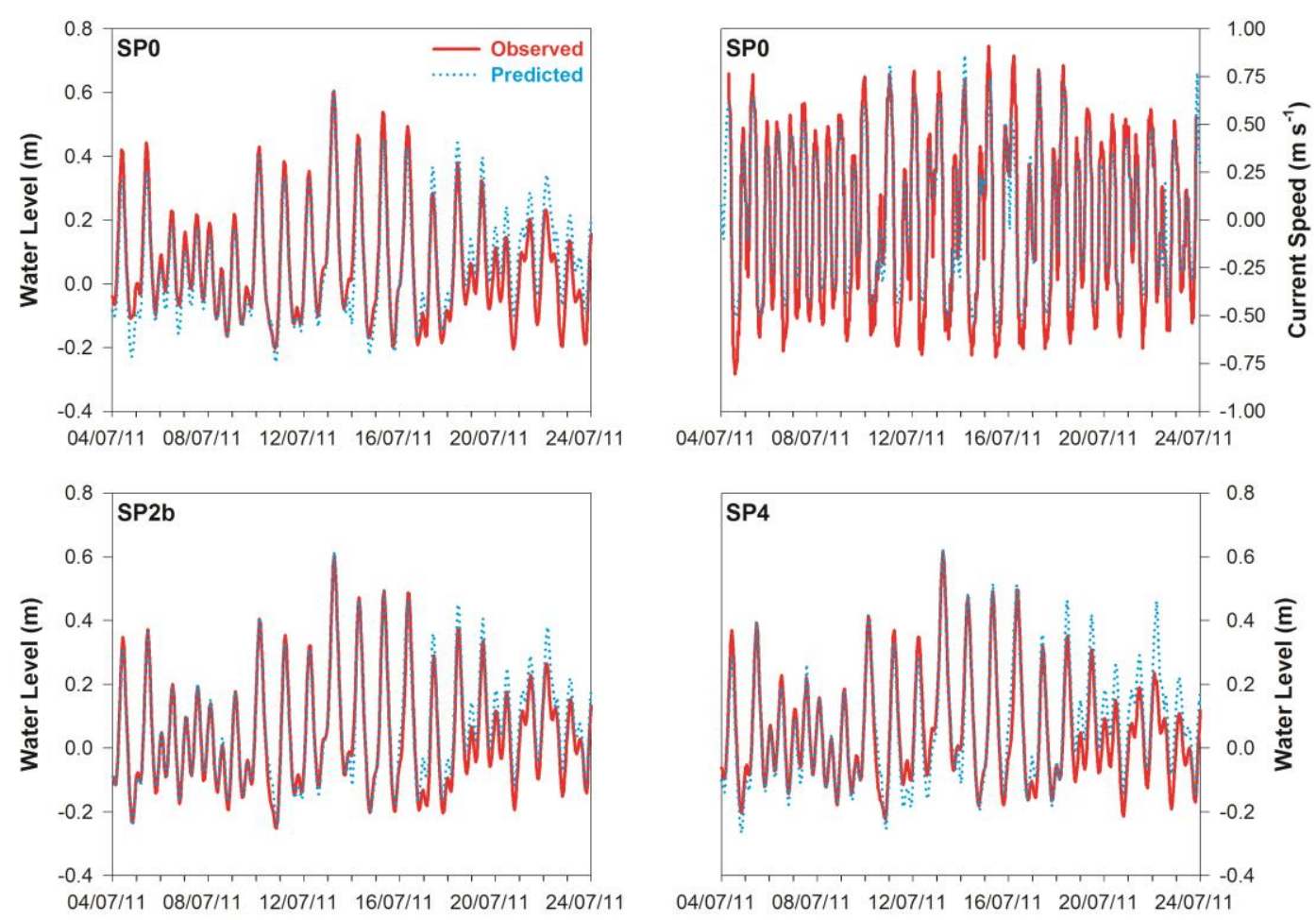

Figure 3 

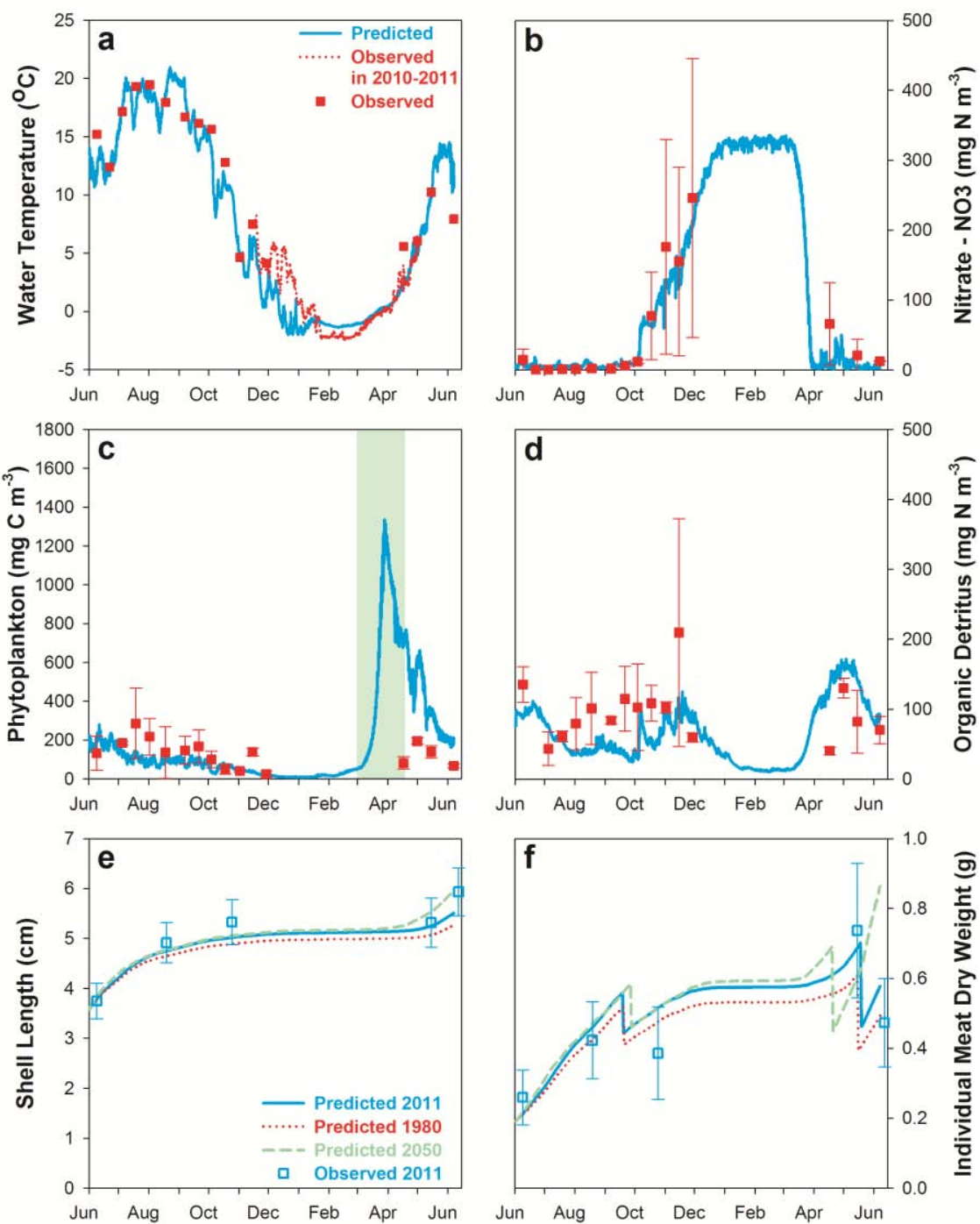

Figure 4

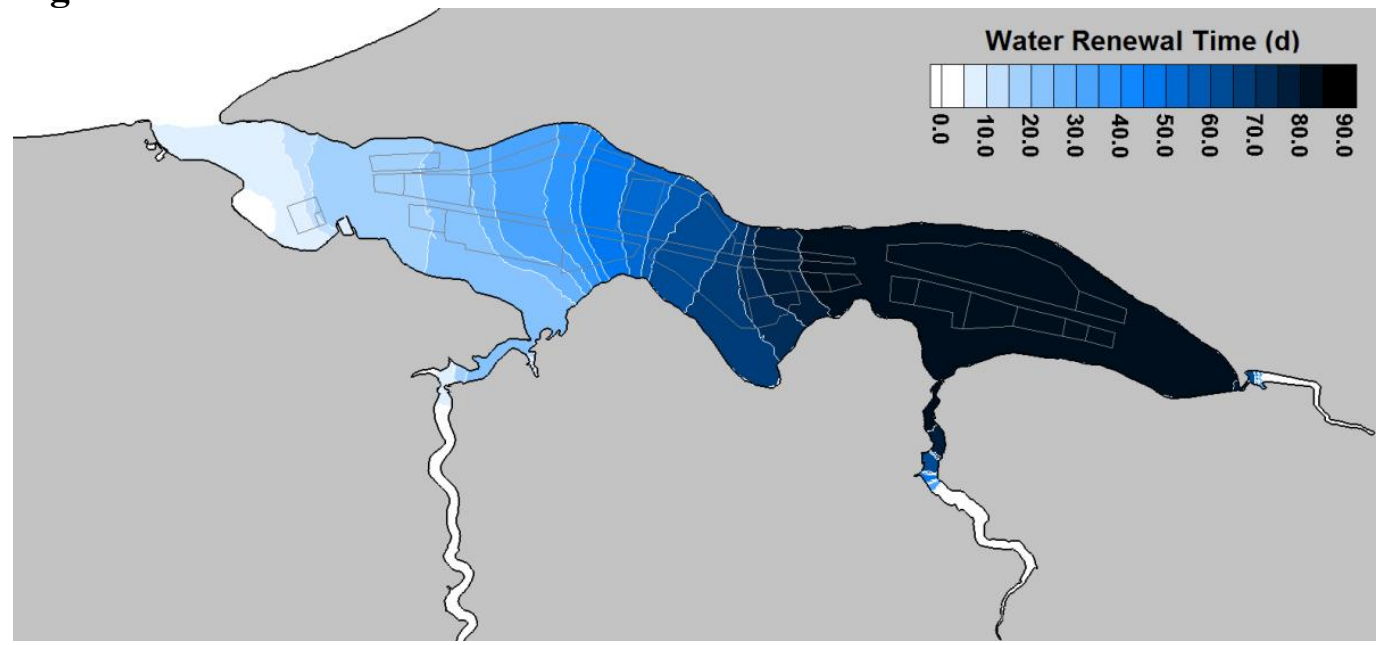

Figure 5 


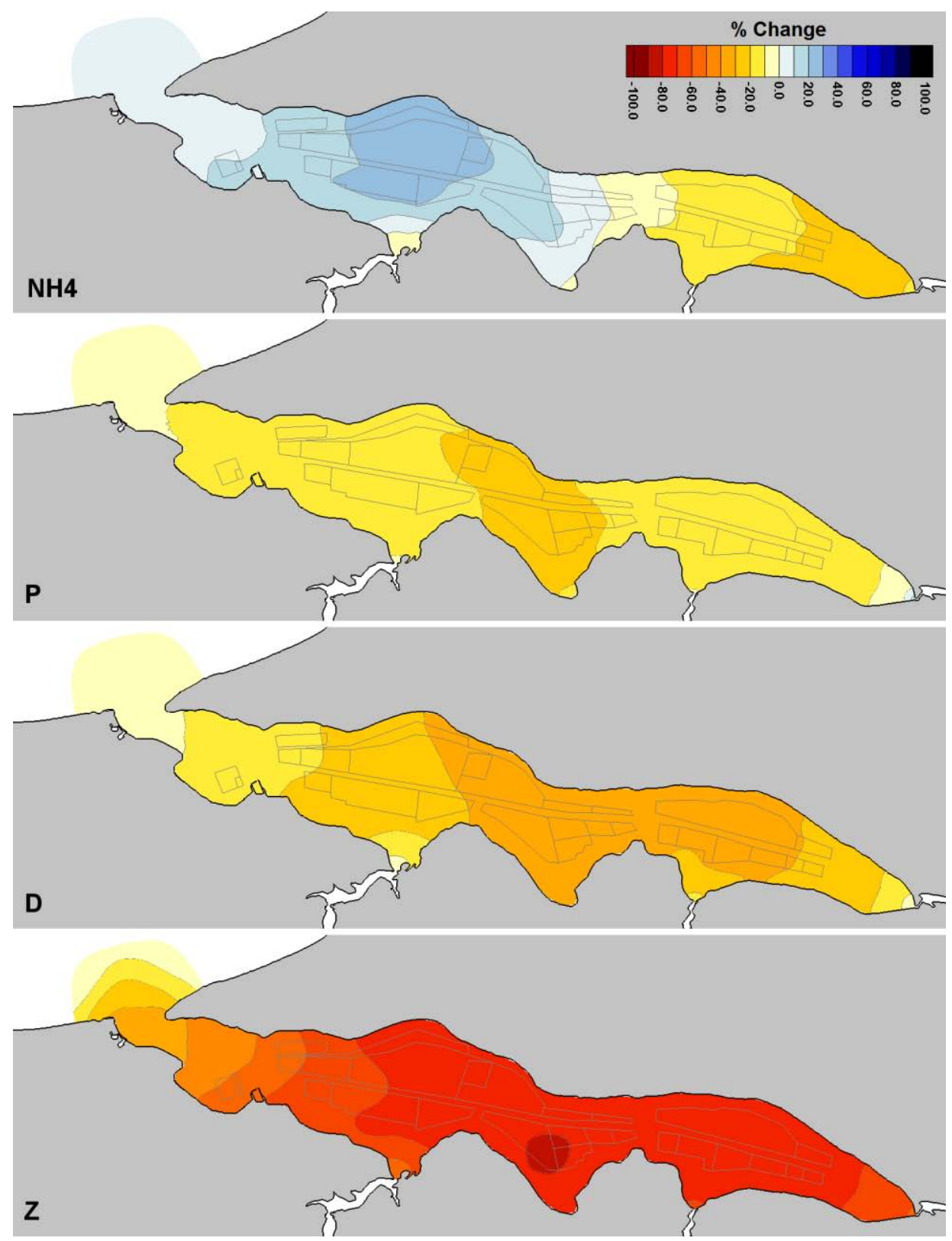

Figure 6 


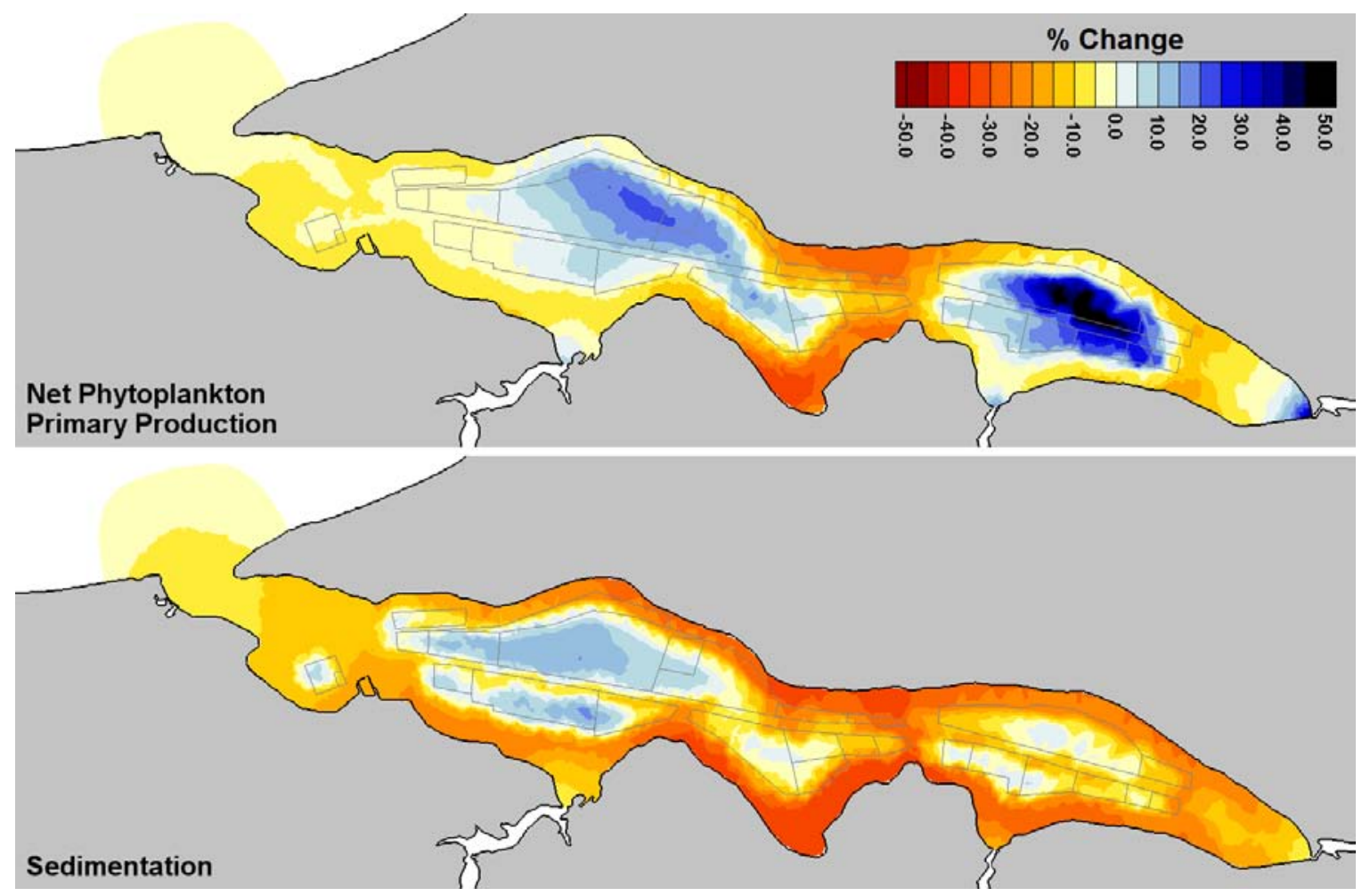

Figure 7 

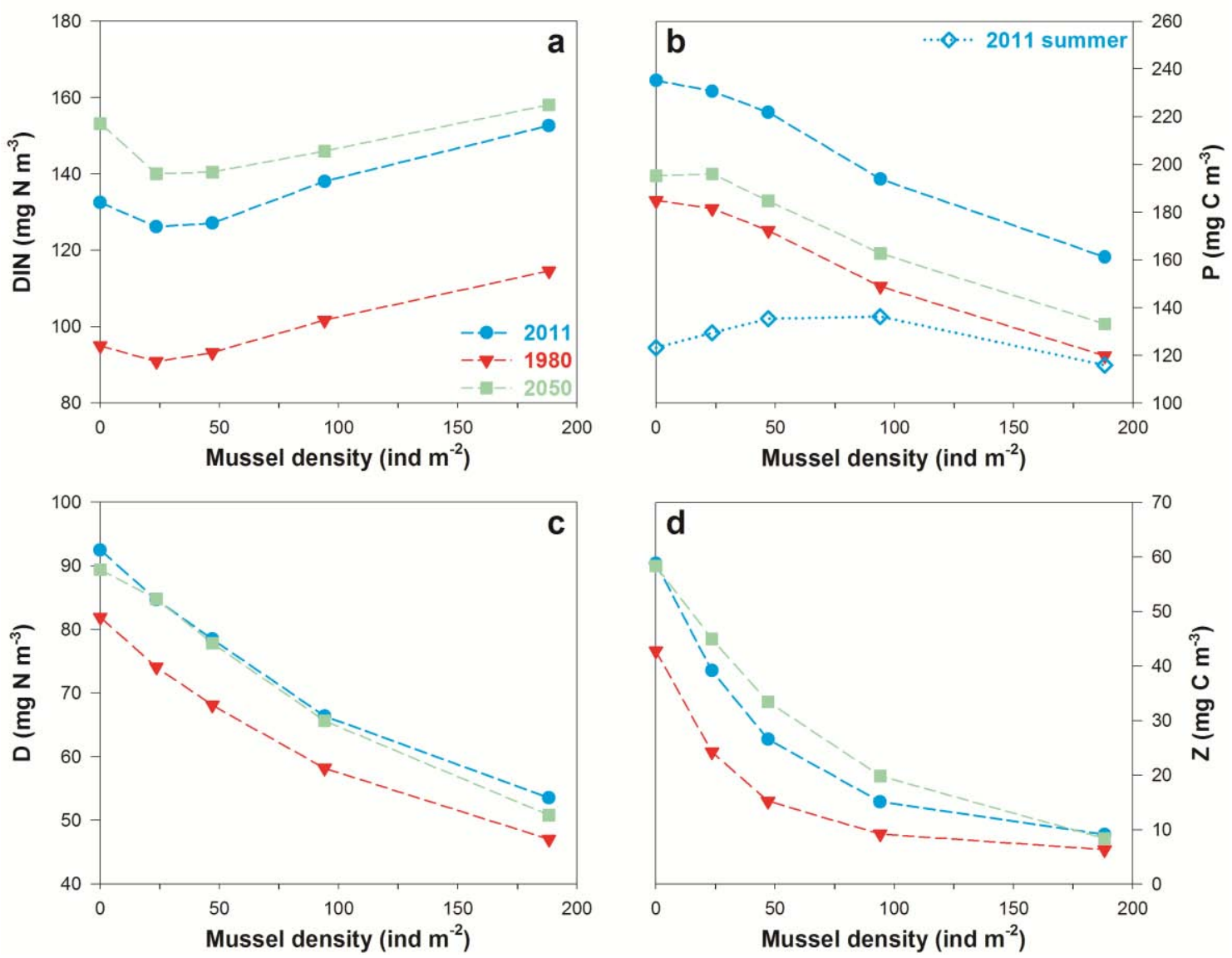

Figure 8

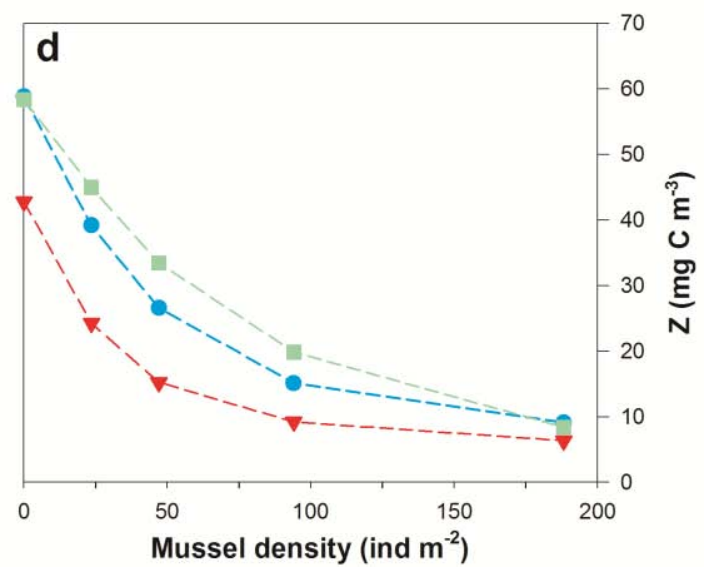



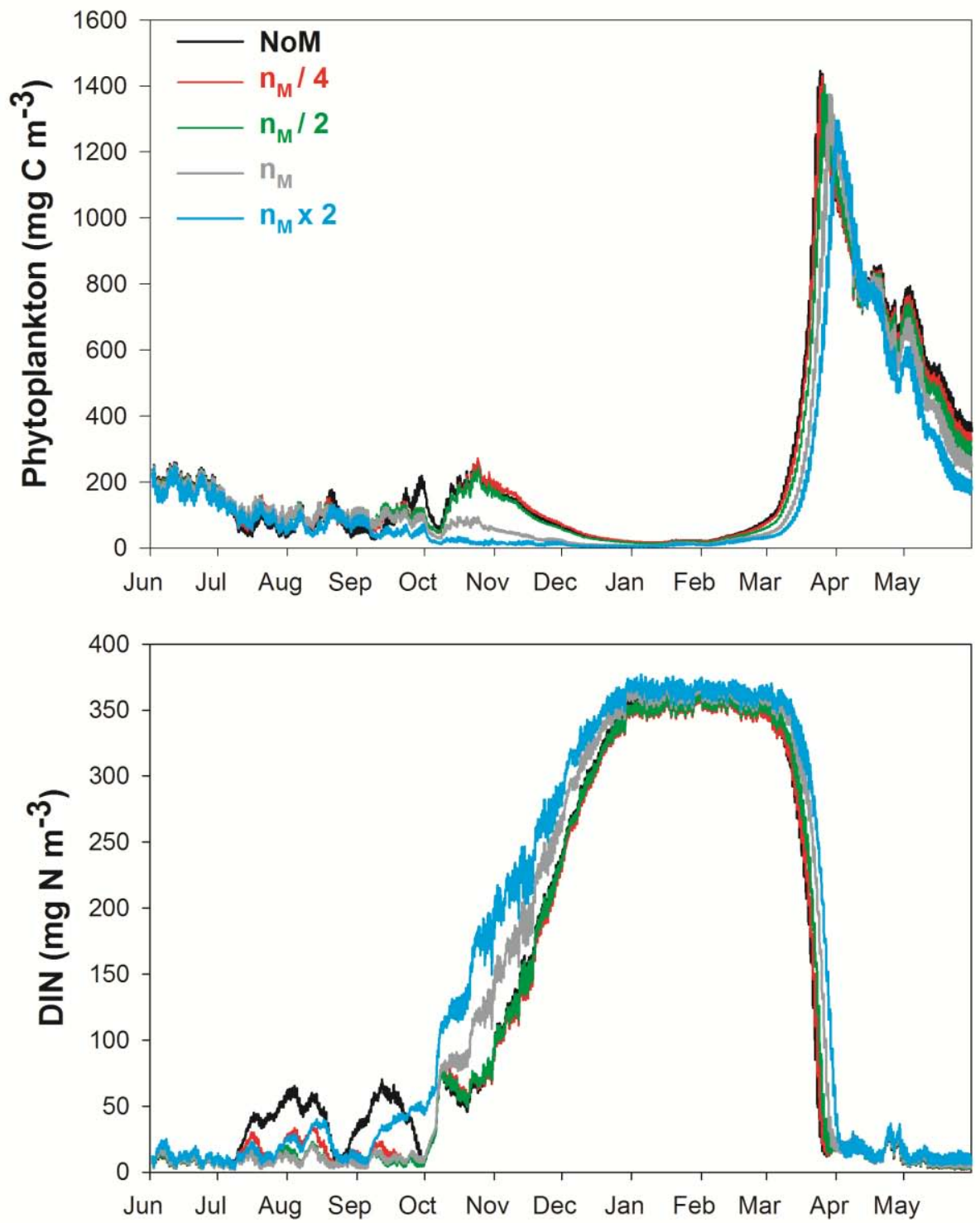

Figure 9 

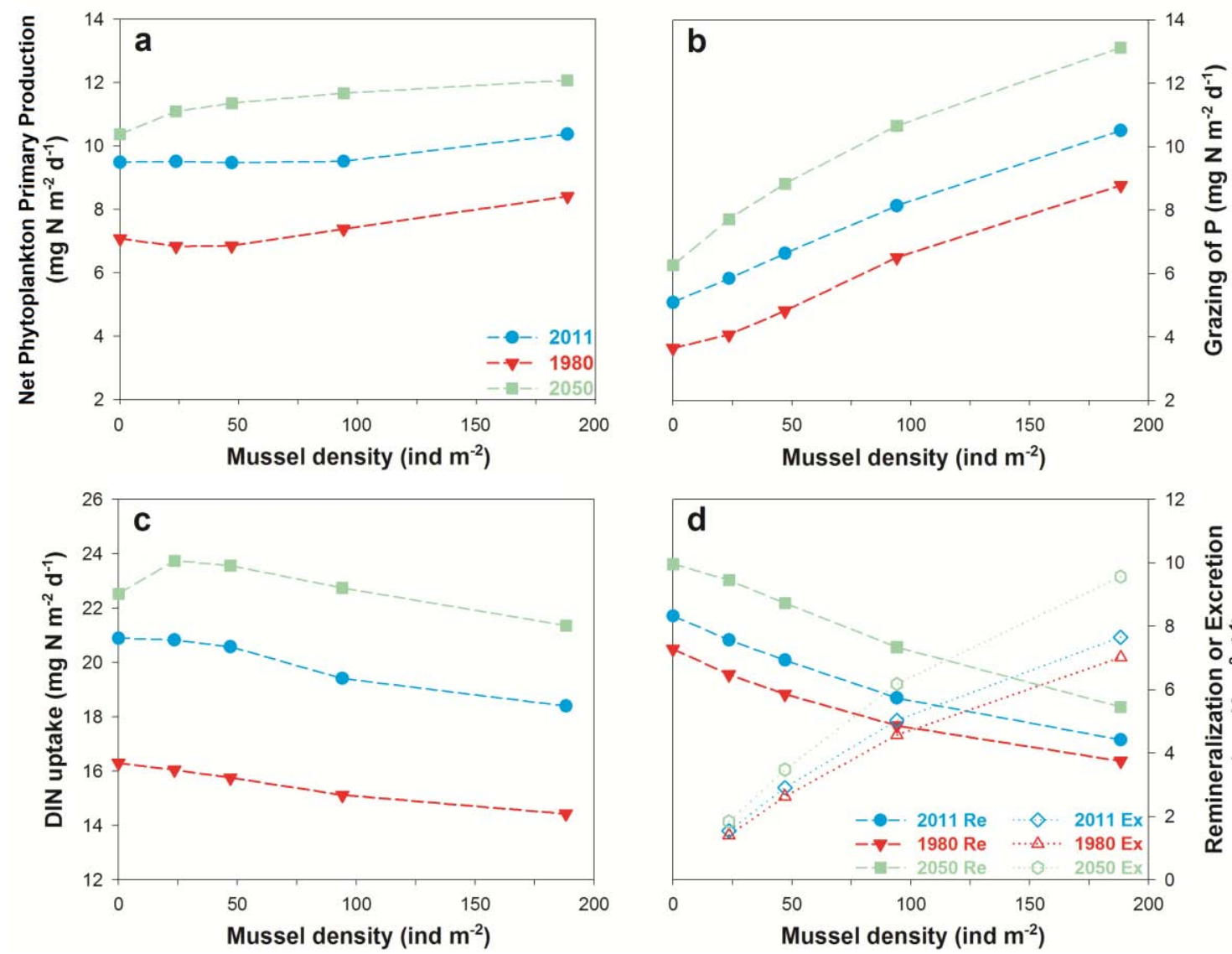

Figure 10

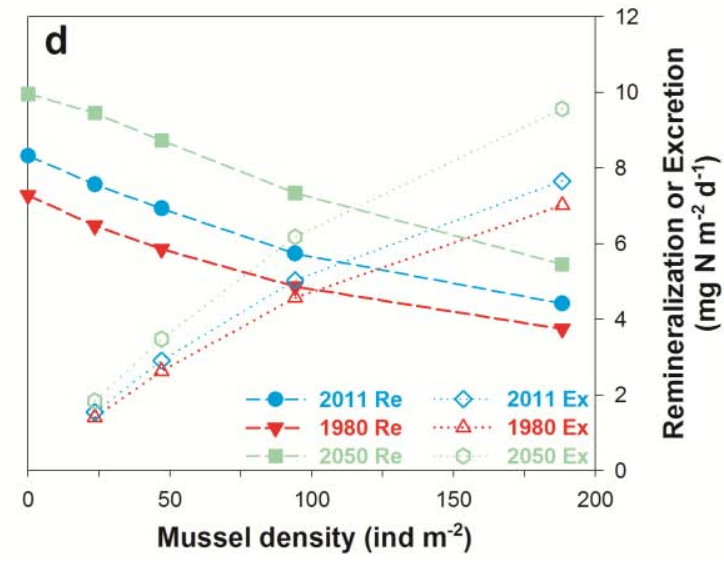

